\title{
Combined effects of water temperature, grazing snails and terrestrial herbivores on leaf decomposition in urban streams
}

\author{
Hongyong Xiang ${ }^{1,2}$, Yixin Zhang ${ }^{\text {Corresp., 1, 3, }}{ }^{\text {, David Atkinson }}{ }^{2}$, Raju Sekar ${ }^{5}$ \\ ${ }^{1}$ Department of Health and Environmental Sciences, Xi'an Jiaotong-Liverpool University, Suzhou, Jiangsu, China \\ 2 Institute of Integrative Biology, University of Liverpool, Liverpool, United Kingdom \\ 3 Xi'an Jiaotong-Liverpool University Huai'an Research Institute of New-Type Urbanization, Huai'an, China \\ 4 Xi'an Jiaotong-Liverpool University Suzhou Urban and Environmental Research Institute, Suzhou, Jiangsu, China \\ 5 Department of Biological Sciences, Xi'an Jiaotong-Liverpool University, Suzhou, Jiangsu, China \\ Corresponding Author: Yixin Zhang \\ Email address: Yixin.Zhang@xjtlu.edu.cn
}

The decomposition of organic matter in freshwaters, such as leaf litter, can affect global nutrient (e.g. carbon) cycling. This process can be influenced by fast urbanization through increased water temperature, reduced aquatic diversity and changed leaf litter quality traits. In this study, we performed a mesocosm experiment to explore the individual and combined effects of warming ( $8{ }^{\circ} \mathrm{C}$ higher and ambient), the presence versus absence of grazing snails (Parafossarulus striatulus), and intraspecific difference of leaf litter quality (intact versus $>40 \%$ area of Liriodendron chinense leaves grazed by terrestrial insects) on litter decomposition in urban streams. Litter decomposition rates ranged from $0.019 \mathrm{~d}^{-1}$ to $0.058 \mathrm{~d}^{-1}$ with an average decomposition rate of $0.032 \pm 0.002 \mathrm{~d}^{-1}$. All the three factors had significant effects on litter decomposition rate. Warming and the presence of snails accelerated litter decomposition rates by $60 \%$ and $35 \%$ respectively. Litter decomposition rates of leaves damaged by terrestrial insects were $5 \%$ slower than that of intact leaves, because litter quality of terrestrial insect-damaged leaves was lower (i.e. higher specific leaf weight) than intact leaves. For treatments with snails, warming stimulated microbial and snail mediated litter decomposition rates by $35 \%$ and $167 \%$, respectively. All combinations of treatments showed additive effects on litter decomposition except for the interaction between warming and snails which showed positive synergistic effects. In addition, neither temperature nor litter quality affected snail growth rate. These results imply that higher water temperature and the presence of abundant snails in urban streams greatly enhanced litter decomposition. Moreover, the effect of pest outbreaks, which resulted in lower litter quality, can cascade to aquatic ecosystems by retarding microbemediated litter decomposition. When these factors co-occurred, warming could 
synergistically interact with snails to speed up the depletion of organic matter, while the effect of leaf quality on litter decomposition may be diminished at high water temperature. These effects could further influence stream food webs and nutrient cycling. 
1 Combined effects of water temperature, grazing snails and terrestrial herbivores on leaf

2 decomposition in urban streams

3 Hongyong Xiang ${ }^{1,2}$, Yixin Zhang ${ }^{1,3,4}$, David Atkinson², Raju Sekar ${ }^{5}$

4 'Department of Health and Environmental Sciences, Xi'an Jiaotong-Liverpool University,

5 Suzhou, China

6 Institute of Integrative Biology, University of Liverpool, Liverpool, United Kingdom

7 'Xi'an Jiaotong-Liverpool University Huai'an Research Institute of New-Type Urbanization,

8 Huai'an, China

$9{ }^{4}$ Xi'an Jiaotong-Liverpool University Suzhou Urban and Environmental Research Institute,

10 Suzhou, China

$11{ }^{5}$ Department of Biological Sciences, Xi'an Jiaotong-Liverpool University, Suzhou, China

\section{Corresponding Author:}

14 Yixin Zhang, Department of Health and Environmental Sciences, Xi'an Jiaotong-Liverpool

15 University, 111 Ren'ai Road, Dushu Lake Higher Education Town, Suzhou Industrial Park, 16 Suzhou, 215123, China.

17 E-mail: Yixin.Zhang@xjtlu.edu.cn 
18 Abstract: The decomposition of organic matter in freshwaters, such as leaf litter, can affect

19 global nutrient (e.g. carbon) cycling. This process can be influenced by fast urbanization through increased water temperature, reduced aquatic diversity and changed leaf litter quality traits. In this study, we performed a mesocosm experiment to explore the individual and combined effects of warming $\left(8^{\circ} \mathrm{C}\right.$ higher and ambient), the presence versus absence of grazing snails (Parafossarulus striatulus), and intraspecific difference of leaf litter quality (intact versus $>40 \%$ area of Liriodendron chinense leaves grazed by terrestrial insects) on litter decomposition in urban streams. Litter decomposition rates ranged from $0.019 \mathrm{~d}^{-1}$ to $0.058 \mathrm{~d}^{-1}$ with an average decomposition rate of $0.032 \pm 0.002 \mathrm{~d}^{-1}$. All the three factors had significant effects on litter decomposition rate. Warming and the presence of snails accelerated litter decomposition rates by $60 \%$ and $35 \%$ respectively. Litter decomposition rates of leaves damaged by terrestrial insects were $5 \%$ slower than that of intact leaves, because litter quality of terrestrial insect-damaged leaves was lower (i.e. higher specific leaf weight) than intact leaves. For treatments with snails, warming stimulated microbial and snail mediated litter decomposition rates by $35 \%$ and $167 \%$, respectively. All combinations of treatments showed additive effects on litter decomposition except for the interaction between warming and snails which showed positive synergistic effects. In addition, neither temperature nor litter quality affected snail growth rate. These results imply that higher water temperature and the presence of abundant snails in urban streams greatly enhanced litter decomposition. Moreover, the effect of pest outbreaks, which resulted in lower

37 litter quality, can cascade to aquatic ecosystems by retarding microbe-mediated litter decomposition. When these factors co-occurred, warming could synergistically interact with snails to speed up the depletion of organic matter, while the effect of leaf quality on litter 
40 decomposition may be diminished at high water temperature. These effects could further

41 influence stream food webs and nutrient cycling.

42 Introduction

43 Global temperature is projected to increase $2.0-4.9^{\circ} \mathrm{C}$ by the end of this century (Raftery et al.

44 2017), and the change in thermal conditions can influence almost all levels of stream ecosystems

45 (Daufresne et al. 2009, Woodward et al. 2010). Numerous studies have indicated that warmer

46 water can accelerate leaf litter (hereafter litter) decomposition in streams (Ferreira and Chauvet

47 2011, Ferreira and Canhoto 2015, Griffiths and Tiegs 2016, Martins et al. 2017). For example,

48 from a synthesis of 1,025 records of litter decomposition, Follstad Shah et al. (2017) found that

49 litter decomposition rates in freshwater ecosystems are expected to accelerate by $5-21 \%$ when

50 water temperature increases $1-4{ }^{\circ} \mathrm{C}$. By contrast, in a global spatial field experiment, Boyero et

51 al. (2011) found that warmer conditions stimulated microbe-mediated litter decomposition

52 whereas invertebrate-mediated litter decomposition was decreased. Consequently, overall litter

53 decomposition rate was unchanged. However, these results may not be suitable for the projection

54 of warming effects on litter decomposition in urban streams, because data from these two global-

55 scale studies were collected from streams with low human-impact intensity. Differences in

56 invertebrate and microbial communities, physical conditions, and other factors were associated

57 with different responses of litter decomposition to water temperature between urban and non-

58 urban (e.g. forest) streams (Imberger et al. 2008, Iñiguez-Armijos et al. 2016, Wenisch et al.

59 2017). For instance, dominant invertebrates in urban streams have broader thermal breadth than

60 invertebrates in mountain forest streams (Giersch et al. 2017). Consequently, warming results in

61 reduced abundance and richness of warming-sensitive invertebrates in forest streams - which are

62 mainly responsible for macroinvertebrate-mediated litter decomposition (Winterbourn et al. 
63 2008, Griffiths and Tiegs 2016). By contrast, warming-induced reduction of abundance and

64 richness of temperature-sensitive invertebrates in urban streams can benefit thermally tolerant

65 invertebrates such as snails - the dominant contributor of macroinvertebrate-mediated litter

66 decomposition (Yule et al. 2015). Therefore, results from most studies that have investigated

67 warming effects on litter decomposition in non-urban streams may not be suitable for urban

68 streams. Urban stream water temperature can be increased through various ways such as

69 deforestation, water intake, discharging warmer effluent from domestic, industrial, and sewage-

70 treatment sources (Lepori et al. 2015), runoff from hot impervious surfaces and stormwater

71 (Somers et al. 2013). Furthermore, as natural stressors usually interact with each other, the

72 effects of warming on litter decomposition are also subjected to seasonal change (Dossena et al.

73 2012, Ferreira and Canhoto 2014), nutrient concentration (Ferreira and Chauvet 2011), and the

74 presence of shredders (Domingos et al. 2015, Moghadam and Zimmer 2016). Thus, predicting

75 the consequences of warming on litter decomposition in urban streams needs to take account of

76 other environmental stressors affecting consumer communities and litter quality.

77 In addition to abiotic factors (e.g. warming), biotic factors such as the presence of aquatic

78 invertebrates (detritivores) can also affect litter decomposition (Jonsson et al. 2001, Gonçalves et

79 al. 2006). Shredders are usually recognized as the dominant contributor to invertebrate-

80 associated litter decomposition in streams (Bruder et al. 2014, Taylor and Andrushchenko 2014).

81 In many tropical and urban streams where shredders were scarce, litter decomposition rates did

82 not differ between coarse and fine mesh bags (i.e. when invertebrates excluded (Pascoal et al.

83 2005). However, these studies may underestimate the role of scrapers in litter decomposition,

84 which shear off food, especially periphyton adhered to leaf surfaces (Cummins and Klug 1979).

85 Specifically, many researchers have found a positive relationship between snail abundance and 
86 litter decomposition rate in streams where diversity and abundance of shredders are low (Suren

87 and McMurtrie 2005, Chadwick et al. 2006, Yule et al. 2015). Snails can colonize litter rapidly

88 even before microbes (e.g. fungi) can develop sufficient biomass or partially degrade the leaf

89 tissues (Casas et al. 2011). Snails can completely eat the soft part of the leaves (Tanaka et al.

90 2006). The presence of snails is likely to affect the microbe-mediated litter decomposition

91 through: 1) changing competition in microbial communities via direct consumption of some

92 microbes such as bacteria; 2) altering microenvironments on the leaf surface due to feeding

93 activities; and 3) stimulating fungal growth by excreting nutrients (e.g. higher ammonia) and

94 labile carbon (Moghadam and Zimmer 2016) or decreasing turbidity which may influence the

95 periphyton biomass (Hann et al. 2001, Li et al. 2008). Snails are abundant in urban streams due

96 to their capability of tolerating high water temperatures and decreased water quality (Gray 2004,

97 Ramírez et al. 2009). In addition, dams can transform upstream reaches from lotic to lentic

98 habitats in rural streams, thereby altering water depth, flow velocity, sediment and water

99 temperature regime (Stanley et al. 2002, Yan et al. 2011, Claeson and Coffin 2016). Although

100 these changes may adversely affect sensitive invertebrates, other organisms including snails

101 could benefit from these modified habitats (Cross et al. 2010, Gangloff et al. 2011). Therefore,

102 snails may be an important factor influencing litter decomposition in these ecosystems and

103 compensate for the loss of sensitive shredders (Chadwick et al. 2006, Casas et al. 2011).

104 Leaf quality has long been acknowledged as an important biotic factor influencing litter

105 decomposition in streams (Leroy and Marks 2006, Hladyz et al. 2009). Generally, high quality

106 leaves (e.g. high nitrogen concentration) are more preferred by invertebrates and microbes, thus

107 making them decompose faster than low quality leaves (Schindler and Gessner 2009). Although

108 numerous studies have investigated the effects of litter quality on its decomposition in 
109 freshwaters, most of them focused on interspecific differences in litter quality (Leroy and Marks

110 2006, Kominoski et al. 2007, Hladyz et al. 2009) rather than intraspecific differences (LeRoy et

111 al. 2007, Jackrel et al. 2016). Environmental and anthropogenic stressors (e.g. insect herbivores,

$112 \mathrm{CO}_{2}$ concentrations, salt, and land use change) can decrease litter quality through various ways

113 such as increasing concentrations of secondary chemicals (e.g. condensed tannins) (Frost et al.

114 2012, Rothman et al. 2015, Jackrel and Morton 2018). For example, plants in warmer urban

115 areas are likely to suffer more serious insect pest outbreaks than in cooler areas (Meineke et al.

116 2013), and insect herbivores may continue to increase in the future due to global climate

117 warming (Meineke et al. 2018). According to the nutrient acceleration hypothesis, insect damage

118 enhances litter decomposition due to accelerated senescence, increased nutrient cycling, and

119 improved litter quality (Chapman et al. 2003). By contrast, as per the nutrient deceleration

120 hypothesis, insect attack can induce higher proportion of secondary defensive compounds which

121 result in decreased nutrient cycling rates (Schweitzer et al. 2005), and thereby reduce litter

122 decomposition rates. The changes in litter quality induced by insect herbivory can cascade to

123 aquatic ecosystems (Jackrel and Wootton 2015, Jackrel and Morton 2018). Therefore, the effects

124 of warming and other stressors associated with urbanization should be coupled with the effects of

125 intraspecific litter quality to accurately estimate their individual and combined effects on

126 ecosystem functioning and organism community structures (LeRoy et al. 2007, Lecerf and

127 Chauvet 2008, Jackrel and Morton 2018). Such combinations of stressors are especially pertinent

128 in urban and mountain areas (high elevation) where terrestrial insects are estimated to cause

129 greater damage to plants, which could result in larger differences in intraspecific litter quality

130 (Chen et al. 2009, Meineke et al. 2013, Ramsfield et al. 2016). 
131 In this study, we used a mesocosm manipulative experiment to explore the effects of increased

132 water temperature $\left(\sim 8^{\circ} \mathrm{C}\right)$ on the decomposition of intact and insect-damaged $(>40 \%$ leaf area

133 were grazed by insects) tulip poplar (Liriodendron chinense), in the presence and absence of

134 snails (Parafossarulus striatulus). Specifically, we aimed to test whether: 1) increasing water

135 temperature would accelerate both microbe- and snail-mediated litter decomposition; 2) leaf

136 damage caused by terrestrial herbivorous insects would reduce litter quality and result in retarded

137 litter decomposition rate; and 3) the presence of snails would increase litter decomposition rate 138 and partly compensate for the loss of shredders.

\section{Materials \& Methods}

141 Leaf litter collection Freshly fallen $L$. chinense leaves were collected during the period $15^{\text {th }}$

142 September to $1^{\text {st }}$ October 2016 from a riparian forest in Jiulongfeng Nature Reserve (mean

143 annual precipitation and air temperature are $1500-1600 \mathrm{~mm}$ and $15.4{ }^{\circ} \mathrm{C}$, respectively), Anhui

144 Province, China (306'39" N, 118 1'21" E). This ca 30-year-old L. chinense woodland had

145 suffered from pests (mainly Lepidoptera: moths, Fig. S1A-B) since 2009. Terrestrial pest

146 outbreak occur twice (June and September) every year. Consequently, the leaf-fall pattern had

147 changed from once at the end of October to twice every year. In the laboratory, leaves were

148 visually grouped into two categories (Fig. S1) according to the ratio of leaf area grazed by 149 insects, i.e. intact-lightly damaged (0-5\%) and heavily damaged ( $>40 \%)$. Then, leaves were 150 oven dried $\left(60{ }^{\circ} \mathrm{C}, 48 \mathrm{~h}\right)$ and weighed prior to use.

151 Experimental design Using $\sim 60 \mathrm{~L}$ aquaria $(50 \times 30 \times 40 \mathrm{~cm})$, factorial combinations of

152 manipulated water temperature (ambient versus $8{ }^{\circ} \mathrm{C}$ above ambient), intraspecific leaf quality

153 (intact versus insect-damaged) and scraper (snail) presence versus absence were each replicated 
154 five times $(2 \times 2 \times 2 \times 5=40$ mesocosms $)$. The experiment lasted for 25 days from $20^{\text {th }}$

155 December 2016 to $14^{\text {th }}$ January 2017. Mesocosms (Fig. S2) were installed on the riparian zone of

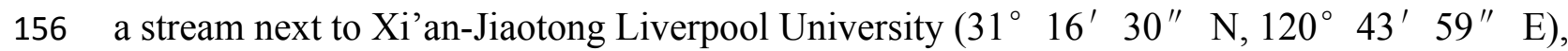

157 Suzhou, China. Water was pumped from the stream and circulated within the mesocosms to

158 emulate the natural water quality, flow, and microbial supply. There was no substrate (e.g.,

159 rocks, gravel, sand) in the mesocosms. In each mesocosm, $10.01 \pm 0.01 \mathrm{~g}$ of unconditioned

160 litter (i.e. dry leaves) were added at the beginning of the experiment. One heating rod (LRB-210,

$161220-240 \mathrm{~V}, 100 \mathrm{~W}$, SunSun Co. Ltd) was used to heat up the water in the warming treatment.

162 The working temperature for the heating rod is $18-34{ }^{\circ} \mathrm{C}$, as average annual air temperature in

163 the study area (Suzhou, China) is $15-17^{\circ} \mathrm{C}$. We set the working temperature as $18^{\circ} \mathrm{C}$ for each

164 heater. In addition, warming usually induced a change of diel temperature oscillation, which can

165 affect litter decomposition (Dang et al. 2009, Vyšná et al. 2014). Therefore, the diel temperature

166 oscillation was also calculated. ]The average increased water temperature was $8^{\circ} \mathrm{C}$ (Fig. 1 and

167 Fig. S4), which is higher than the projected range of temperature increases by the end of this

168 century globally $\left(2.0-4.9^{\circ} \mathrm{C}\right)$ (Raftery et al. 2017) and for China $\left(3.9-6.0^{\circ} \mathrm{C}\right)$ (Ding et al.

169 2006). This extreme high temperature may still be possible in urban areas where air temperature

170 could be $1-3{ }^{\circ} \mathrm{C}$ warmer than rural areas, and the difference in air temperature between urban

171 and rural areas can be as large as $10{ }^{\circ} \mathrm{C}$ under certain conditions (e.g. calm, cloudless nights in

172 winter) (Grimmond 2007). In addition, for big cities such as Shanghai, China, the projected

173 increase of mean temperature is estimated to be 2.5 times of that for global mean temperature

174 (Chu et al. 2016). As water temperature in most streams would increase $0.6-0.8{ }^{\circ} \mathrm{C}$ for every $1{ }^{\circ} \mathrm{C}$

175 increase in air temperature (Morrill Jean et al. 2005), an $8^{\circ} \mathrm{C}$ increase in water temperature

176 would be realistic for streams in big cities. Moreover, an increase of $8{ }^{\circ} \mathrm{C}$ is not rare for 
177 laboratory microcosm studies (Ferreira and Chauvet 2011, Fernandes et al. 2012, Geraldes et al.

178 2012). Nine temperature loggers (ONSET, Stow Away TidbiT Temp Logger) were randomly

179 placed into nine mesocosms (five warmed; four at ambient water temperature) to record water

180 temperature once every hour during the experimental period (Dataset S1 and Fig. S3). Dissolved

181 oxygen (DO), conductivity, and ammonia were measured using a YSI (Pro Plus), and pH and

182 turbidity were measured using pH (CLEAN, PH30) and turbidity (HACH, 2100Q) meter,

183 respectively, before conducting the experiment, and then on days 5, 14, and 24. On day 25 , the

184 litter (Fig. S5) was collected using a hand-held net, oven dried (60 $\left.{ }^{\circ} \mathrm{C}, 48 \mathrm{~h}\right)$, and then weighed to 185 calculate litter decomposition rate.

186 Water temperature Water temperature was successfully increased in mesocosms with the

187 warming treatment (mean $\pm \mathrm{SE}, 18.5 \pm 0.54{ }^{\circ} \mathrm{C}$ ) by an average of $8{ }^{\circ} \mathrm{C}$ above that in ambient 188 treatment mesocosms (mean $\left.\pm \mathrm{SE}, 10.5 \pm 0.14^{\circ} \mathrm{C}\right)$ during the experimental period $(t=14.537, \mathrm{df}$ $189=4.502, P<0.001$, Figure 1a and $\mathrm{S} 1$ in supporting information). However, diel temperature 190 oscillation did not differ between warming $\left(2.83 \pm 0.24{ }^{\circ} \mathrm{C}\right)$ and ambient $\left(2.86 \pm 0.10^{\circ} \mathrm{C}\right)$

191 treatments $(t=-0.124, \mathrm{df}=5.274, P=0.906$, Fig. $1 \mathrm{~b})$. Water quality measures (Table 1 and Table 192 S1 and Dataset S2 in supporting information, Fig. 2) were also significantly affected by the 193 treatments (for more details, see the supplementary methods).

194 Specific leaf weight Specific leaf weight (SLW, leaf dry weight per unit leaf area) can be 195 regarded as an indicator of leaf toughness - an important litter quality trait (Steinbauer 2001).

196 SLW was measured to test the potential physical structural quality differences between insect 197 damaged and intact litter, because plants tend to have higher SLW when attacked by insects 198 (Nabeshima et al. 2001, Sudderth and Bazzaz 2008). Thirty intact and insect-damaged leaves 199 were randomly selected from the leaves collected for this study. For each focal leaf, one leaf disc 
200 (6 mm in diameter, avoiding leaf vein) was randomly cut out using a core borer. All leaf discs

201 were oven dried $\left(60^{\circ} \mathrm{C}\right)$ to constant weight, which was recorded to the nearest $0.0001 \mathrm{~g}$ (Dataset

202 S3). Then, SLW was calculated by dividing the dry leaf mass to leaf disc area (Jackrel et al.

203 2016).

204 Snail Specimens of a common snail P. striatulus were collected from a stream to the north of

205 Renmin University of China, Suzhou $\left(31^{\circ} 16^{\prime} 54^{\prime \prime} \mathrm{N}, 120^{\circ} 44^{\prime} 30^{\prime \prime}\right.$ E). This stream is

206 straight, $\sim 15 \mathrm{~m}$ wide, with muddy sediment and concrete bank. Snails were kept in mesocosms

207 for at least one week to acclimate to the new environment and were starved for three days before

208 conducting the experiment. Before starting the experiment, each snail was blotted dry and

209 weighed to the nearest $0.0001 \mathrm{~g}$ (mean \pm S.E, $1.0744 \pm 0.0322 \mathrm{~g}, \mathrm{n}=400$, Dataset S4). Twenty

210 randomly selected snails were placed in each scraper treatment, giving a density of $133 \mathrm{ind} / \mathrm{m}^{2}$,

211 which was higher than the mean natural density $\left(41-80\right.$ ind. $\left./ \mathrm{m}^{2}\right)$ but still within the natural range

212 of population density (0-280 ind. $\left./ \mathrm{m}^{2}\right)$ in this area (Wang and Hong 2010, Hu et al. 2013). At the

213 end of the experiment, snails were blotted dry and weighed again to determine the growth rate.

214 Then, all snails were released to the stream where they were collected. Snail growth rates were

215 calculated as $\mu=\left[\ln \left(\mathrm{W}_{\mathrm{t}}\right)-\ln \left(\mathrm{W}_{0}\right)\right] / \mathrm{t}$, where $\mathrm{W}_{\mathrm{t}}$ and $\mathrm{W}_{0}$ were blotted mean wet mass per

216 treatment at the end of the experiment (day t) and before the experiment, respectively (Hill et al.

217 2010). In addition, snail tissue dry mass (TDM) and ash free dry mass (AFDM) were calculated

218 using empirical equations in the study area (i.e. Suzhou, China), TDM=0.067W, and

219 AFDM=0.286W, where W was blotted dry mass (Zhao et al. 2009).

220 Litter decomposition Litter decomposition rates (Dataset S5) were calculated assuming an

221 exponential decay $\left(k, \mathrm{~d}^{-1}\right), \mathrm{W}_{\mathrm{t}}=\mathrm{W}_{\mathrm{I}} \times \mathrm{e}^{-\mathrm{kt}}\left(\right.$ Eq. 1), where $\mathrm{W}_{\mathrm{t}}$ represents the remaining leaf mass at

222 the incubation time $\mathrm{t}$ (day) and $\mathrm{W}_{\mathrm{I}}$ is the initial mass of leaf material (Ferreira and Chauvet 
223 2011). In addition, we calculated the sensitivities of litter decomposition rates to temperature:

$224 \mathrm{Q}_{10-\mathrm{q}}=\left(\mathrm{t}_{\mathrm{A}} / \mathrm{t}_{\mathrm{W}}\right)^{(10 /(T w-T a)}(\mathrm{Eq} .2)\left(\right.$ Conant et al. 2008), where $\mathrm{t}_{\mathrm{A}}$ and $\mathrm{t}_{\mathrm{W}}$ are the time (days) to

225 decompose $50 \%$ of initial dry leaf mass at the ambient and warming temperature respectively,

$226 T a$ and $T w$ are the mean temperature during the experimental period in the ambient and warming

227 mesocosms respectively. Litter decomposition rates in the presence and absence of snails was

228 total $\left(k_{\text {total }}\right)$ and microbe-mediated $\left(k_{\text {microbial }}\right)$ litter decomposition rates respectively. The

229 contribution of snail-mediated litter decomposition rate was estimated by the difference in dry

230 leaf mass remains between mesocosms in the presence and absence of snails, and then

231 calculating a new $k$ value ( $\left.k_{\text {snail }}\right)$ (Magali et al. 2016, Mosele Tonin et al. 2018).

232 Data analysis Three-way ANOVA was used to test for differences in litter decomposition rates

233 among treatments (warming, snail grazing, litter quality). In treatments with the presence of

234 snails, two-way ANOVA was used to test the effects of warming and litter quality on litter

235 decomposition rates, i.e., $k_{\text {total }}, k_{\text {microbial }}$, and $k_{\text {snail }}$.

236 T-tests were used to test for differences in water temperature (daily mean water temperature and

237 diel temperature oscillation) between warming and ambient treatments (Domingos et al. 2015,

238 Ferreira et al. 2015). For each measured water quality variable, we used three-way ANOVA

239 (analysis of variance) with repeated measures (RM ANOVA) to explore the effects of

240 experimental treatments on water quality. A t-test was used to check for SLW differences

241 between intact and insect-damaged leaves. One-way ANOVA was used to detect whether initial

242 blotted dry mass differed among the four treatments with snails. If they differed among

243 treatments, then, initial blotted dry mass was set as a co-variable when doing the two-way

244 ANCOVA to test the potential effect of body size on snail growth rate and litter decomposition

245 rate. As both TDM and AFDM are correlated with blotted dry mass, we only analyzed two-way 
246 ANOVA results of net blotted dry mass growth rates. To determine the interaction type of two-

247 way interactions, we followed the methods proposed by (Piggott et al. 2015). After conducting

248 normality tests for all data, the data were transformed (e.g. log) to improve the normality of data.

249 All data were analyzed using SPSS 22.0.

250

251 Results

252 Leaf litter decomposition Litter decomposition rates varied between $0.019 \mathrm{~d}^{-1}$ and $0.058 \mathrm{~d}^{-1}$

253 (mean \pm S.E, $0.032 \pm 0.002 \mathrm{~d}^{-1}$, Fig. 3, Fig. S3). Warming accelerated litter decomposition rates

254 by $60 \%$ (data were log-transformed, $F_{1,32}=259.93, P<0.001$, Table 2 ). The presence of snails

$255\left(0.037 \pm 0.001 \mathrm{~d}^{-1}\right)$ also significantly increased litter decomposition rates by $35 \%\left(F_{1,32}=90.21\right.$,

$256 P<0.001$, Table 2). However, litter decomposition rates of terrestrial insect-damaged leaves

$257\left(0.031 \pm 0.001 \mathrm{~d}^{-1}\right)$ were $5 \%$ slower than those of intact leaves $\left(F_{1,32}=4.687, P=0.038\right.$, Table 2$)$.

258 The interaction of temperature and snail presence had positive synergistic effects on litter

259 decomposition, i.e. warming increased the litter decomposition rates more in the presence of

260 snails than in their absence. However, neither the rest of the two-way interactions nor the three-

261 way interactions had significant effects on litter decomposition rates, i.e. the rest of the

262 interactions all showed additive effects.

263 The overall sensitivity of litter decomposition rates to temperature $\left(\mathrm{Q}_{10-\mathrm{q}}\right)$ was low according to a

264 classification system reported previously (Conant et al. 2008). When mean temperature increased

265 from $10.5{ }^{\circ} \mathrm{C}$ to $18.5^{\circ} \mathrm{C}$, the litter decomposition was stimulated more in the presence of snails

266 than in their absence for both intact leaves $\left(Q_{10-q}=2.38\right.$ vs. 1.66) and insect damaged leaves $\left(Q_{10-q}\right.$

$267=2.37$ vs. 1.61). However, the thermal sensitivity of litter decomposition rates showed no 
268 difference between the intact and insect-damaged leaves in the presence $\left(Q_{10-q}=2.38\right.$ vs. 2.37$)$ and

269 absence $\left(\mathrm{Q}_{10-\mathrm{q}}=1.66\right.$ vs. 1.61) of snails.

270 In treatments with snails, warming significantly increased total, microbial-, and snail-mediated

271 litter decomposition rates by $81 \%, 35 \%$, and $167 \%$, respectively $(P<0.001$, Table 3, Fig. 4).

272 Microbe-mediated litter decomposition rates were also $7 \%$ lower for damaged leaves than intact

273 leaves $\left(F_{1,15}=5.417, P=0.034\right.$, Table 3). By contrast, neither total nor snail-mediated litter

274 decomposition rates were affected by litter quality. Water temperature and litter quality showed

275 additive effects on each of the three measures of litter decomposition rate (Table 3 ). In addition,

276 in the presence of snails, even though initial blotted dry mass differed among the four treatments

$277\left(F_{3,16}=3.893, P=0.029\right.$, Fig. $\left.5 \mathrm{c}\right)$, none of the litter decomposition rates were affected by initial

278 dry mass of snails (Table 3).

279 Specific leaf weight Mean ( \pm S.E.) SLW of terrestrial insect-grazed leaves $\left(7.9 \pm 0.4 \mathrm{mg} / \mathrm{cm}^{2}\right)$

280 were $47 \%$ higher than that of intact leaves $\left(5.4 \pm 0.4 \mathrm{mg} / \mathrm{cm}^{2} ; t=-4.872, \mathrm{df}=58, P<0.001\right.$, see

281 Dataset S3 in supporting information).

282 Snail growth There were no significant differences among treatments for snail growth rates

283 (Table 4, Fig. 5A). Snail growth rates were negligible (close to 0, almost ceased growth) and net

284 blotted dry biomass kept constant during the experiment (no significant difference was shown

285 between initial and final blotted dry biomass).

286

287 Discussion

288 Warming enhanced litter decomposition

289 Litter decomposition rates were significantly increased in warming treatments, which agrees with

290 previous findings (Martínez et al. 2014, Ferreira et al. 2015), increasing by $7.5 \%$ per ${ }^{\circ} \mathrm{C}$ 
291 warming (mean $\left.\mathrm{Q}_{10-\mathrm{q}}=1.79\right)$. This acceleration is nearer to the estimated $10 \%$ acceleration of

292 litter decomposition rate per ${ }^{\circ} \mathrm{C}$ in the tropics rather than the $2.5 \%$ in temperate biomes

293 (Follstad Shah et al. 2017). Correa-Araneda et al. (2015)indicated that warmer conditions can

294 depress abundance and species richness of macroinvertebrates with narrow thermal tolerance

295 thereby reducing litter decomposition rate (. However, if the depressed macroinvertebrate-

296 mediated litter decomposition was compensated by stimulated microbe-mediated litter

297 decomposition, then overall litter decomposition would be unchanged (Boyero et al. 2011) or

298 even higher than under ambient conditions (Dossena et al. 2012). Our results indicated that

299 warming can not only enhance microbe-mediated litter decomposition (Fernandes et al. 2012,

300 Ferreira and Canhoto 2015), but also can accelerate snail-mediated litter decomposition (Friberg

301 et al. 2009). Previous studies also found that microbe-mediated litter decomposition in urban

302 streams was enhanced by the increased water temperature (Imberger et al. 2008, Yule et al.

303 2015). However, in urban streams with poor water quality (e.g. low DO and high ammonia),

304 microbe-mediated litter decomposition would decrease, countering any increase with warmer

305 water temperature (Martins et al. 2015, Iñiguez-Armijos et al. 2016). Therefore, it is important to

306 take physicochemical factors into consideration when assessing the impact of increasing water

307 temperature on litter decomposition in urban streams. For invertebrate-mediated litter

308 decomposition, our result differs from that of Domingos et al. (2015) in which $\sim 3{ }^{\circ} \mathrm{C}$ higher

309 water temperature depressed the activity of Allogamus laureatus (Trichoptera, Limnephilidae),

310 leading to a lack of thermal stimulation of litter decomposition in the presence of A. laureatus .

311 Thus, we suggest that differences in the invertebrate community can influence the effects of

312 warming on invertebrate-mediated litter decomposition. 
313 In addition, along with increased mean water temperature, higher diel temperature oscillation,

314 which is usually associated with climate warming, can also contribute to accelerated litter

315 decomposition rate (Dang et al. 2009, Vyšná et al. 2014, Gonçalves et al. 2015). However, this

316 was unlikely in this study, as diel temperature oscillation did not differ between warming and

317 ambient treatments. Moreover, the effects of litter quality on both microbe- and snail-mediated

318 litter decomposition rates diminished at higher water temperature, which accords with the

319 suggestion of Fernandes et al. (2012) that warming (from 18 to $24{ }^{\circ} \mathrm{C}$ in their microcosms) could

320 weaken the effects of litter quality on microbe-mediated (fungal) litter decomposition. Therefore,

321 even though warming and other factors (e.g. increasing concentration of $\mathrm{CO}_{2}$ ) associated with

322 urbanization can alter litter quality (Tuchman et al. 2002, Meineke et al. 2013), these effects may

323 be overridden by the effects of warming on litter decomposition in freshwaters.

\section{The presence of snails accelerated litter decomposition}

325 The presence of scrapers (snails) accelerated litter decomposition rates by $35 \%$. Our results

326 suggest that the presence of snails in urban streams, where shredders are often scarce or absent,

327 play an important role in litter decomposition, as also found by Chadwick et al. (2006). We

328 found that leaf morphology in treatments with snails differed from treatments without snails,

329 indicating likely effects of grazing on the leaf surface. However, we could not ascertain whether

330 leaf morphological changes arose from direct consumption of leaves by snails or from the

331 indirect effects of grazing on algae attached to the leaf surface. The snails almost ceased growth

332 in this study which was probably due to the overall low activities of snails in winter

333 (Eleutheriadis and Lazaridou-Dimitriadou 2001), or because we used unconditioned leaves and

33425 days may not be long enough for sufficient colonization by microbes (Wallace et al. 1970).

335 Collectively, the presence of snails in urban streams can significantly accelerate litter 
336 decomposition in winter, even though snail growth rates were almost zero. Additionally,

337 warming can synergistically enhance the effects of snails on litter decomposition. Due to the

338 global increase of urban areas, we can anticipate that shredder-mediated litter decomposition

339 would decrease while snail-mediated litter decomposition would be enhanced. In addition, water

340 temperature would also likely increase as rural streams are transformed into urban streams,

341 resulting in exaggerated snail-mediated litter decomposition.

342 Terrestrial insect herbivores retarded litter decomposition

343 Decomposition rates of terrestrial insect-grazed leaves were $5 \%$ slower than those of intact

344 leaves. The retarded litter decomposition was caused by lower litter quality, as indicated by (1)

345 higher SLW of terrestrial insect-grazed litter ( $>40 \%$ leaf area) than intact leaves $(<5 \%$ leaf area

346 grazed), because a higher SLW has been associated with lower leaf N, P and N:P ratio (Wu et al.

347 2012), and (2) even though snail-mediated litter decomposition rates did not differ between intact

348 and insect-damaged leaves, higher litter decomposition rates were found for insect-damaged

349 leaves than for intact leaves under ambient conditions, because snails need to consume more

350 insect-damaged leaves to compensate for the lower quality to meet their metabolic requirements

351 (Flores et al. 2014). These results suggest that insect herbivores decreased litter quality

352 (Peschiutta et al. 2018), thereby supporting the nutrient deceleration hypothesis. Another

353 possible mechanism is that insect herbivory resulted in higher concentrations of secondary

354 compounds in deciduous trees (Chapman et al. 2006). The lower litter quality had different

355 effects on snails and microbes, with significantly slower microbe-mediated decomposition but

356 faster (but not significant) snail-mediated decomposition in ambient conditions. This result is

357 similar to that of LeRoy et al. (2007) in which aquatic fungi could discriminate intraspecific litter

358 quality differences, whereas macroinvertebrates could not. LeRoy et al. (2007) suggested that 
359 aquatic fungi may respond to quality differences in litter. Snail-mediated litter decomposition

360 showed a weak relationship to intraspecific litter quality difference, possibly because: (1) the

361 effects of litter quality diffused through trophic levels, and (2) large body size of snails enable

362 them to tolerate many toxicant secondary compounds (Yule et al. 2009). In addition, the

363 differences in litter decomposition rates between insect-damaged and intact L. chinensis leaves in

364 this study (5\%) was much smaller than that of Jackrel and Wootton (2015) who observed $42 \%$

365 faster decomposition of intact Alnus rubra leaves than of herbivory-treated leaves (Jackrel and

366 Wootton 2015). The reason for this difference may be that litter quality of L. chinensis may be

367 poorer than Alnus rubra: C:N stoichiometryof L. tulipifera (C:N, 36.69-56.3) (Kominoski et al.

368 2007, Ardón et al. 2009, Griffiths and Tiegs 2016), may reflect that of the congeneric $L$.

369 chinensis, and is higher (i.e. suggesting poorer quality) than that of $A$. rubra (C:N were 21.11

370 and 18.73 for herbivory treated and control respectively). Therefore, a further herbivore-induced

371 decline in the already less palatable Liriodendron might not make a big difference for

372 consumers. Although we only found increased $\mathrm{pH}$ in treatments with damaged leaves, other

373 water quality characters may also have been potentially influenced by the difference of

374 intraspecific litter quality (Adams et al. 2003), and consequently affect litter decomposition. Our

375 findings imply that when considering the importance of litter quality on decomposition in

376 streams, we should consider not only interspecific differences but also intraspecific differences

377 in litter, especially considering that future climate change, land use change, and other stressors

378 can change intraspecific litter quality (Graça and Poquet 2014, Fey et al. 2015, Pincebourde et al.

379 2017).

380 The interactions of water temperature, snail, and litter quality on litter decomposition 
381 Among all the two-way combinations, only that between snails and water temperature showed

382 positive synergistic effects on litter decomposition rates, whereas all other combinations showed

383 additive effects (i.e. no significant interaction). The macroinvertebrate-warming synergistic

384 effects on litter decomposition rates, also observed by Moghadam and Zimmer (2016), could be

385 explained by enhanced consumption rates of litter by snails at higher temperature conditions

386 because of higher metabolic demands of snails at these high temperatures (Seuffert et al. 2010,

387 Gordon et al. 2018). Warming can increase the community-level energy demand with

388 consequences for ecosystem functioning (Nelson et al. 2017). At higher water temperatures,

389 snails often feed more selectively on higher quality food (Gordon et al. 2018). This could be the

390 reason why snail-mediated litter decomposition was more sensitive to temperature for intact

391 leaves than for insect-damaged leaves. In addition, litter quality would be increased (e.g. reduced

392 toughness, fewer phenols and lower $\mathrm{C}: \mathrm{N}$ ratios) when incubated at higher water temperature

393 (Esther et al. 2015). Interactive effects of litter quality and water temperature on litter

394 decomposition are difficult to predict because of conflicting types of interaction including

395 warming either reinforcing poor litter-quality effects on decomposition (Correa-Araneda et al.

396 2015, Esther et al. 2015), dampening the effects of lignin-rich (i.e. poor quality) litter on

397 decomposition (Fernandes et al. 2012), or additively interacting with litter quality to affect litter

398 decomposition (Correa-Araneda et al. 2017). Our results supported a disappearance of the effects

399 of litter quality on litter decomposition at high water temperatures. These results imply that even

400 though the presence of snails can increase litter decomposition in urban streams, most of the

401 carbon stored in litter is released by microbes and transformed into $\mathrm{CO}_{2}$. Decomposition of lower

402 quality litter is expected to be more stimulated by microbes than is higher quality litter at high

403 water temperature condition. By contrast, snail-mediated litter decomposition may be more 
404 sensitive to the change of water temperature for high rather than low quality litter. Therefore, the

405 effect of warming on nutrient cycling in urban streams depends on litter quality.

\section{Implications for urban stream management and conservation}

407 Our results indicate that reducing the impacts of warming should be the most important way to

408 alter organic matter decomposition in urban streams, rather than the other two factors

409 (intraspecific litter quality difference and the presence of snails). Warming can also induce a

410 change of DO concentration, terrestrial subsidy input (quality, quantity, and input time of litter),

411 and macroinvertebrate and microbial communities, which are among the 26 key research

412 questions in urban stream ecology (Wenger et al. 2009), and consequently affect nutrient cycling

413 (e.g. carbon) in these waterbodies. The effects of warming on nutrient (e.g. carbon) cycling

414 through litter decomposition in streams depend on how much of this carbon goes into

415 invertebrates (invertebrates converted litter to particulate and dissolved forms of carbon) or

416 microbes (microbes released the carbon stored in litter to gaseous form) (Boyero et al. 2011,

417 Follstad Shah et al. 2017). This implies that $\mathrm{CO}_{2}$ production via litter decomposition in urban

418 streams might increase with warming, as well as the generation of particulate or dissolved

419 carbon. However, this projection would be improved if we were able to know how future climate

420 change would affect the quantity and quality of litter, and macroinvertebrate communities in

421 freshwaters. Considering that urban streams are expected to suffer more serious stress from

422 warming than rural streams, it is urgent to take actions to alleviate their negative effects on

423 freshwaters. In particular, given the predicted increase in urban land cover of 1.2 million $\mathrm{km}^{2}$ by

424 2030, which is three times the global urban land area in 2000 (Seto et al. 2012), more streams

425 will clearly be affected by this land-use change. Conservation actions to mitigate the effects of

426 climate warming on urban ecosystems include: (1) increasing urban forest cover by sequestering 
$427 \mathrm{CO}_{2}$ (Bowler et al. 2010, Blum 2016) and reducing storm water runoff (McPherson et al. 1997);

428 (2) enhancing hyporheic exchange and adopting different wastewater treatment strategies

429 through accelerated heat exchange with other media such as atmosphere and subsurface

430 groundwater (Kaushal et al. 2010); (3) decreasing the quantity of water withdrawals by reducing

431 the warming effects induced by impoundments (Webb and Nobilis 1995) and (4) increasing the

432 reuse of treated wastewater (Kinouchi 2007).

433

\section{Conclusions}

435 In summary, we found that (1) litter decomposition rates were stimulated by increasing water

436 temperature $\left(\sim 8{ }^{\circ} \mathrm{C}\right.$ higher than ambient) through increased activities of microbes and

437 invertebrates (snails); (2) the presence of grazing snails (scrapers) accelerated litter

438 decomposition rate through their direct consumption of leaf material or indirectly by scraping

439 microbes attached to leaf surfaces, and these effects were stronger at raised water temperature

440 than at ambient water temperature; and (3) terrestrial herbivorous insects retarded microbe-

441 mediated litter decomposition by inducing higher SLW of litter (i.e. poorer litter quality), and the

442 effects of litter quality on both microbial and snail mediated litter decomposition diminished at

443 higher water temperature. Thus, although the increasing terrestrial insect herbivory could lead to

444 lower litter quality that can retard litter decomposition (Adams et al. 2003, Meineke et al. 2018),

445 warming is expected to stimulate both microbe- and snail-mediated litter decomposition in urban

446 streams.

447

448 Acknowledgments 
449 We thank Ting Zhang and Ying Hua for their help in collecting snails and setting up the

450 mesocosm experiment. We also thank for the valuable comments given by Dr. Alan Tonin and

451 other anonymous reviewers which are very helpful in improving the quality of this manuscript.

452

453

\section{References}

454

455

456

457

458

459

460

461

462

463

464

465

466

467

468

469

470

Adams, J. A., N. C. Tuchman, and P. A. Moore. 2003. Atmospheric $\mathrm{CO}_{2}$ enrichment alters leaf detritus: impacts on foraging decisions of crayfish (Orconectes virilis). Journal of the North American Benthological Society 22:410-422.

Ardón, M., C. M. Pringle, and S. L. Eggert. 2009. Does leaf chemistry differentially affect breakdown in tropical vs temperate streams? Importance of standardized analytical techniques to measure leaf chemistry. Journal of the North American Benthological Society 28:440-453.

Blum, J. 2016. Contribution of ecosystem services to air quality and climate change mitigation policies: the case of urban forests in Barcelona, Spain. Pages 21-54 Urban Forests. Apple Academic Press.

Bowler, D. E., L. Buyung-Ali, T. M. Knight, and A. S. Pullin. 2010. Urban greening to cool towns and cities: A systematic review of the empirical evidence. Landscape and Urban Planning 97:147-155.

Boyero, L., R. G. Pearson, M. O. Gessner, L. A. Barmuta, V. Ferreira, M. A. Graça, D. Dudgeon, A. J. Boulton, M. Callisto, and E. Chauvet. 2011. A global experiment suggests climate warming will not accelerate litter decomposition in streams but might reduce carbon sequestration. Ecology Letters 14:289-294. 
471 Bruder, A., M. H. Schindler, M. S. Moretti, and M. O. Gessner. 2014. Litter decomposition in a

472

473

474

475

476

477

478

479

480

481

482

483

484

485

486

487

488

489

490

491

492

493

temperate and a tropical stream: the effects of species mixing, litter quality and shredders. Freshwater Biology 59:438-449.

Casas, J. J., M. O. Gessner, D. López, and E. Descals. 2011. Leaf-litter colonisation and breakdown in relation to stream typology: insights from Mediterranean low-order streams. Freshwater Biology 56:2594-2608.

Chadwick, M. A., D. R. Dobberfuhl, A. C. Benke, A. D. Huryn, K. Suberkropp, and J. E. Thiele. 2006. Urbanization affects stream ecosystem function by altering hydrology, chemistry, and biotic richness. Ecological Applications 16:1796-1807.

Chapman, S. K., S. C. Hart, N. S. Cobb, T. G. Whitham, and G. W. Koch. 2003. Insect herbivory increases litter quality and decomposition: an extension of the acceleration hypothesis. Ecology 84:2867-2876.

Chapman, S. K., T. G. Whitham, and M. Powell. 2006. Herbivory differentially alters plant litter dynamics of evergreen and deciduous trees. Oikos 114:566-574.

Chen, I. C., H.-J. Shiu, S. Benedick, J. D. Holloway, V. K. Cheye, H. S. Barlow, J. K. Hill, and C. D. Thomas. 2009. Elevation increases in moth assemblages over 42 years on a tropical mountain. Proceedings of the National Academy of Sciences of the United States of America 106:1479-1483.

Chu, W., S. Qiu, and J. Xu. 2016. Temperature change of Shanghai and its response to global warming and urbanization. Atmosphere 7.

Claeson, S. M., and B. Coffin. 2016. Physical and biological responses to an alternative removal strategy of a moderate-sized dam in Washington, USA. River Research and Applications 32:1143-1152.

Peer) reviewing PDF | (2019:03:36291:2:0:NEW 13 Jul 2019) 
494 Conant, R. T., R. A. Drijber, M. L. Haddix, W. J. Parton, E. A. Paul, A. F. Plante, J. Six, and J. M. 495 Steinweg. 2008. Sensitivity of organic matter decomposition to warming varies with its 496 quality. Global Change Biology 14:868-877.

497 Correa-Araneda, F., L. Boyero, R. Figueroa, C. Sánchez, R. Abdala, A. Ruiz-García, and M. A. S. 498 Graça. 2015. Joint effects of climate warming and exotic litter (Eucalyptus globulus Labill.) on stream detritivore fitness and litter breakdown. Aquatic Sciences 77:197-205.

Correa - Araneda, F., A. Basaguren, A. D. R. T., T. A. Mosele, and B. Luz. 2017.

501

502

503

504

505

506

507

508

509

510

511

512

513

514

515

516
Resource - allocation tradeoffs in caddisflies facing multiple stressors. Ecology and Evolution 7:5103-5110.

Cross, W. F., E. J. Rosi-Marshall, K. E. Behn, T. A. Kennedy, R. O. Hall, Jr., A. E. Fuller, and C. V. Baxter. 2010. Invasion and production of New Zealand mud snails in the Colorado River, Glen Canyon. Biological Invasions 12:3033-3043.

Cummins, K. W., and M. J. Klug. 1979. Feeding ecology of stream invertebrates. Annual Review of Ecology and Systematics 10:147-172.

Dang, C. K., M. Schindler, E. Chauvet, and M. O. Gessner. 2009. Temperature oscillation coupled with fungal community shifts can modulate warming effects on litter decomposition. Ecology 90:122-131.

Daufresne, M., K. Lengfellner, and U. Sommer. 2009. Global warming benefits the small in aquatic ecosystems. Proceedings of the National Academy of Sciences of the United States of America 106:12788-12793.

Ding, Y., G. Ren, G. Shi, P. Gong, X. Zheng, P. Zhai, D. Zhang, Z. Zhao, S. Wang, and H. Wang. 2006. National assessment report of climate change (I): climate change in China and its future trend. Advances in Climate Change Research 2:3-8. 
517 Domingos, C., V. Ferreira, C. Canhoto, and C. Swan. 2015. Warming, and the presence of a 518 dominant shredder, drive variation in decomposer communities in a mountain stream. $519 \quad$ Aquatic Sciences 77:129-140.

520 Dossena, M., G. Yvon-Durocher, J. Grey, J. M. Montoya, D. M. Perkins, M. Trimmer, and G. Woodward. 2012. Warming alters community size structure and ecosystem functioning. Proceedings of the Royal Society B-Biological Sciences 279:3011-3019.

523 Eleutheriadis, N., and M. Lazaridou-Dimitriadou. 2001. The life cycle, population dynamics, growth and secondary production of Bithynia graeca (Westerlund, 1879) (Gastropoda) in Lake Kerkini, Northern Greece. Journal of Molluscan Studies 67:319-328.

Esther, M. M., M. Isabel, O. Francesc, and C. Cristina. 2015. Effects of increased water temperature on leaf litter quality and detritivore performance: a whole - reach

Fernandes, I., C. Pascoal, H. Guimarães, R. Pinto, I. Sousa, and F. Cássio. 2012. Higher temperature reduces the effects of litter quality on decomposition by aquatic fungi.

Ferreira, V., and C. Canhoto. 2014. Effect of experimental and seasonal warming on litter 533 decomposition in a temperate stream. Aquatic Sciences 76:155-163.

534 Ferreira, V., and C. Canhoto. 2015. Future increase in temperature may stimulate litter 535 decomposition in temperate mountain streams: evidence from a stream manipulation 536 experiment. Freshwater Biology 60:881-892.

537 Ferreira, V., and E. Chauvet. 2011. Synergistic effects of water temperature and dissolved nutrients 538 on litter decomposition and associated fungi. Global Change Biology 17:551-564. 
539 Ferreira, V., E. Chauvet, and C. Canhoto. 2015. Effects of experimental warming, litter species, 540 and presence of macroinvertebrates on litter decomposition and associated decomposers in a temperate mountain stream. Canadian Journal of Fisheries and Aquatic Sciences 72:206216.

543

544

545

546

547

548

549

550

551

552

553

554

555

556

557

558

559

Fey, S. B., A. N. Mertens, L. J. Beversdorf, K. D. McMahon, and K. L. Cottingham. 2015. Recognizing cross - ecosystem responses to changing temperatures: soil warming impacts pelagic food webs. Oikos 124:1473-1481.

Flores, L., A. Larrañaga, and A. Elosegi. 2014. Compensatory feeding of a stream detritivore alleviates the effects of poor food quality when enough food is supplied. Freshwater Science 33:134-141.

Follstad Shah, J. J., J. S. Kominoski, M. Ardon, W. K. Dodds, M. O. Gessner, N. A. Griffiths, C. P. Hawkins, S. L. Johnson, A. Lecerf, C. J. LeRoy, D. W. P. Manning, A. D. Rosemond, R. L. Sinsabaugh, C. M. Swan, J. R. Webster, and L. H. Zeglin. 2017. Global synthesis of the temperature sensitivity of leaf litter breakdown in streams and rivers. Global Change Biology 23:3064-3075.

Friberg, N., J. B. Dybkjær, J. S. Olafsson, G. M. Gislason, S. E. Larsen, and T. L. Lauridsen. 2009. Relationships between structure and function in streams contrasting in temperature. Freshwater Biology 54:2051-2068.

Frost, C. J., J. M. Dean, E. C. Smyers, M. C. Mescher, J. E. Carlson, C. M. De Moraes, and J. F. Tooker. 2012. A petiole-galling insect herbivore decelerates leaf lamina litter decomposition rates. Functional Ecology 26:628-636. 
560 Gangloff, M. M., E. E. Hartfield, D. C. Werneke, and J. W. Feminella. 2011. Associations between

561

562

563

564

565

566

567

568

569

570

571

572

573

574

575

576

577

578

579

580

581

582 small dams and mollusk assemblages in Alabama streams. Journal of the North American Benthological Society 30:1107-1116.

Geraldes, P., C. Pascoal, and F. Cássio. 2012. Effects of increased temperature and aquatic fungal diversity on litter decomposition. Fungal Ecology 5:734-740.

Giersch, J. J., S. Hotaling, R. P. Kovach, L. A. Jones, and C. C. Muhlfeld. 2017. Climate-induced glacier and snow loss imperils alpine stream insects. Global Change Biology 23:25772589.

Gonçalves, A. L., M. A. S. Graça, and C. Canhoto. 2015. Is diversity a buffer against environmental temperature fluctuations? - A decomposition experiment with aquatic fungi. Fungal Ecology 17:96-102.

Gonçalves, J. F., M. A. S. Graça, and M. Callisto. 2006. Leaf-litter breakdown in 3 streams in temperate, Mediterranean, and tropical Cerrado climates. Journal of the North American Benthological Society 25:344-355.

Gordon, T. A. C., J. Neto-Cerejeira, P. C. Furey, and E. J. O’Gorman. 2018. Changes in feeding selectivity of freshwater invertebrates across a natural thermal gradient. Current Zoology 64:231-242.

Graça, M. A. S., and J. M. Poquet. 2014. Do climate and soil influence phenotypic variability in leaf litter, microbial decomposition and shredder consumption? Oecologia 174:1021-1032.

Gray, L. 2004. Changes in water quality and macroinvertebrate communities resulting from urban stormflows in the Provo River, Utah, U.S.A. Hydrobiologia 518:33-46.

Griffiths, N. A., and S. D. Tiegs. 2016. Organic-matter decomposition along a temperature gradient in a forested headwater stream. Freshwater Science 35:518-533.

Peer) reviewing PDF | (2019:03:36291:2:0:NEW 13 Jul 2019) 
583 Grimmond, S. 2007. Urbanization and global environmental change: local effects of urban 584 warming. The Geographical Journal 173:83-88.

585 586 587 588 589 590 591 592 593 594 595 596 597 598

599

600

601

602 603

Hann, B. J., C. J. Mundy, and L. G. Goldsborough. 2001. Snail-periphyton interactions in a prairie lacustrine wetland. Hydrobiologia 457:167-175.

Hill, W. R., J. G. Smith, and A. J. Stewart. 2010. Light, nutrients, and herbivore growth in oligotrophic streams. Ecology 91:518-527.

Hladyz, S., M. O. Gessner, P. S. Giller, J. Pozo, and G. Woodward. 2009. Resource quality and stoichiometric constraints on stream ecosystem functioning. Freshwater Biology 54:957970.

Hu, Z., S. Wang, Y. Zhang, Y. Zhang, Q. Liu, and Y. Zha. 2013. Community characteristics of macrozoobenthos in Backshore Wetland of Expo Garden, Shanghai, China and their application on bio-assessment of water quality. Acta Scientiae Circumstantiae 33:10801088.

Iñiguez-Armijos, C., S. Rausche, A. Cueva, A. Sánchez-Rodríguez, C. Espinosa, and L. Breuer. 2016. Shifts in leaf litter breakdown along a forest-pasture-urban gradient in Andean streams. Ecology and Evolution 6:4849-4865.

Imberger, S. J., C. J. Walsh, and M. R. Grace. 2008. More microbial activity, not abrasive flow or shredder abundance, accelerates breakdown of labile leaf litter in urban streams. Journal of the North American Benthological Society 27:549-561.

Jackrel, S. L., and T. C. Morton. 2018. Inducible phenotypic plasticity in plants regulates aquatic ecosystem functioning. Oecologia 186:895-906.

Peer) reviewing PDF | (2019:03:36291:2:0:NEW 13 Jul 2019) 
604 Jackrel, S. L., T. C. Morton, and J. T. Wootton. 2016. Intraspecific leaf chemistry drives locally 605 accelerated ecosystem function in aquatic and terrestrial communities. Ecology 97:21256062135.

607 Jackrel, S. L., and J. T. Wootton. 2015. Cascading effects of induced terrestrial plant defences on 608 aquatic and terrestrial ecosystem function. Proceedings of the Royal Society B-Biological $609 \quad$ Sciences 282.

610 Jonsson, M., B. Malmqvist, and P. O. Hoffsten. 2001. Leaf litter breakdown rates in boreal streams: 611 does shredder species richness matter? Freshwater Biology 46:161-171.

612 Kaushal, S. S., G. E. Likens, N. A. Jaworski, M. L. Pace, A. M. Sides, D. Seekell, K. T. Belt, D. H. Secor, and R. L. Wingate. 2010. Rising stream and river temperatures in the United States. Frontiers in Ecology and the Environment 8:461-466.

615 Kinouchi, T. 2007. Impact of long-term water and energy consumption in Tokyo on wastewater 616 effluent: implications for the thermal degradation of urban streams. Hydrological Processes 21:1207-1216.

Lecerf, A., and E. Chauvet. 2008. Intraspecific variability in leaf traits strongly affects alder leaf 622 decomposition in a stream. Basic and Applied Ecology 9:598-605.

Lepori, F., M. Pozzoni, and S. Pera. 2015. What drives warming trends in streams? A case study from the Alpine foothills. River Research and Applications 31:663-675.

Leroy, C. J., and J. C. Marks. 2006. Litter quality, stream characteristics and litter diversity influence decomposition rates and macroinvertebrates. Freshwater Biology 51:605-617. 
627 LeRoy, C. J., T. G. Whitham, S. C. Wooley, and J. C. Marks. 2007. Within-species variation in 628 foliar chemistry influences leaf-litter decomposition in a Utah river. Journal of the North American Benthological Society 26:426-438.

630

631

632

633

634

635

636

637

638

639

640

641

642

643

644

645

646

647

648

Li, K. Y., Z. W. Liu, and B. H. Gu. 2008. Persistence of clear water in a nutrient-impacted region of Lake Taihu: The role of periphyton grazing by snails. Fundamental and Applied Limnology 173:15-20.

Magali, B., L. Sylvain, and C. Eric. 2016. Litter breakdown for ecosystem integrity assessment also applies to streams affected by pesticides. Hydrobiologia 773:87-102.

Martínez, A., A. Larrañaga, J. Pérez, E. Descals, and J. Pozo. 2014. Temperature affects leaf litter decomposition in low-order forest streams: field and microcosm approaches. Fems Microbiology Ecology 87:257-267.

Martins, R. T., A. S. Melo, J. F. Gonçalves, C. M. Campos, and N. Hamada. 2017. Effects of climate change on leaf breakdown by microorganisms and the shredder Phylloicus elektoros (Trichoptera: Calamoceratidae). Hydrobiologia 789:31-44.

Martins, R. T., A. S. Melo, J. F. Gonçalves Jr, and N. Hamada. 2015. Leaf-litter breakdown in urban streams of Central Amazonia: direct and indirect effects of physical, chemical, and biological factors. Freshwater Science 34:716-726.

McPherson, E. G., D. Nowak, G. Heisler, S. Grimmond, C. Souch, R. Grant, and R. Rowntree. 1997. Quantifying urban forest structure, function, and value: the Chicago Urban Forest Climate Project. Urban Ecosystems 1:49-61.

Meineke, E. K., A. T. Classen, N. J. Sanders, and T. Jonathan Davies. 2018. Herbarium specimens reveal increasing herbivory over the past century. Journal of Ecology 0:1-13.

Peer) reviewing PDF | (2019:03:36291:2:0:NEW 13 Jul 2019) 
649 Meineke, E. K., R. R. Dunn, J. O. Sexton, and S. D. Frank. 2013. Urban warming drives insect $650 \quad$ pest abundance on street trees. Plos One 8:e59687.

651 Moghadam, F. S., and M. Zimmer. 2016. Effects of warming, nutrient enrichment and detritivore 652 presence on litter breakdown and associated microbial decomposers in a simulated 653 temperate woodland creek. Hydrobiologia 770:243-256.

654 655

656

657

658

659

660

661

662

663

664

665

666

667

668

669

670

671

Morrill Jean, C., C. Bales Roger, and H. Conklin Martha. 2005. Estimating Stream Temperature from Air Temperature: Implications for Future Water Quality. Journal of Environmental Engineering 131:139-146.

Mosele Tonin, A., L. Ubiratan Hepp, and J. F. Gonçalves. 2018. Spatial variability of plant litter decomposition in stream networks: from litter bags to watersheds. Ecosystems 21:567-581.

Nabeshima, E., M. Murakami, and T. Hiura. 2001. Effects of Herbivory and Light Conditions on Induced Defense in Quercus crispula. Journal of Plant Research 114:403-409.

Nelson, D., J. P. Benstead, A. D. Huryn, W. F. Cross, J. M. Hood, P. W. Johnson, J. R. Junker, G. M. Gíslason, and J. S. Ólafsson. 2017. Experimental whole-stream warming alters community size structure. Global Change Biology 23:2618-2628.

Pascoal, C., F. Cássio, A. Marcotegui, B. Sanz, and P. Gomes. 2005. Role of fungi, bacteria, and invertebrates in leaf litter breakdown in a polluted river. Journal of the North American Benthological Society 24:784-797.

Peschiutta, M. L., F. G. Scholz, G. Goldstein, and S. J. Bucci. 2018. Oviposition by herbivorous insects induces changes in optical and mechanical properties of Prunus avium leaves. Arthropod-Plant Interactions 12:613-622.

Piggott, J. J., C. R. Townsend, and C. D. Matthaei. 2015. Reconceptualizing synergism and antagonism among multiple stressors. Ecology and Evolution 5:1538-1547. 
672 Pincebourde, S., J. van Baaren, S. Rasmann, P. Rasmont, G. Rodet, B. Martinet, and P. A. 673 Calatayud. 2017. Chapter Nine - Plant-Insect Interactions in a Changing World. Pages

674

675

676

677

678

679

680

681

682

683

684

685

686

687

688

689

690

691

692

693

694 289-332 in N. Sauvion, D. Thiéry, and P.-A. Calatayud, editors. Advances in Botanical Research. Academic Press.

Raftery, A. E., A. Zimmer, D. M. W. Frierson, R. Startz, and P. Liu. 2017. Less than $2{ }^{\circ}$ C warming by 2100 unlikely. Nature Climate Change 7:637.

Ramírez, A., R. De Jesús-Crespo, D. M. Martinó-Cardona, N. Martínez-Rivera, and S. BurgosCaraballo. 2009. Urban streams in Puerto Rico: what can we learn from the tropics? Journal of the North American Benthological Society 28:1070-1079.

Ramsfield, T. D., B. J. Bentz, M. Faccoli, H. Jactel, and E. G. Brockerhoff. 2016. Forest health in a changing world: effects of globalization and climate change on forest insect and pathogen impacts. Forestry: An International Journal of Forest Research 89:245-252.

Rothman, J. M., C. A. Chapman, T. T. Struhsaker, D. Raubenheimer, D. Twinomugisha, and P. G. Waterman. 2015. Long-term declines in nutritional quality of tropical leaves. Ecology 96:873-878.

Schindler, M. H., and M. O. Gessner. 2009. Functional leaf traits and biodiversity effects on litter decomposition in a stream. Ecology 90:1641-1649.

Schweitzer, J. A., J. K. Bailey, S. C. Hart, G. M. Wimp, S. K. Chapman, and T. G. Whitham. 2005. The interaction of plant genotype and herbivory decelerate leaf litter decomposition and alter nutrient dynamics. Oikos 110:133-145.

Seto, K. C., B. Güneralp, and L. R. Hutyra. 2012. Global forecasts of urban expansion to 2030 and direct impacts on biodiversity and carbon pools. Proceedings of the National Academy of Sciences 109:16083-16088. 
695 Seuffert, M. E., S. Burela, and P. R. Martín. 2010. Influence of water temperature on the activity 696 of the freshwater snail Pomacea canaliculata (Caenogastropoda: Ampullariidae) at its 697 southernmost limit (Southern Pampas, Argentina). Journal of Thermal Biology 35:77-84.

698

699

700

701

702

703

704

705

706

707

708

709

710

711

712

713

714

715

716

717

Somers, K. A., E. S. Bernhardt, J. B. Grace, B. A. Hassett, E. B. Sudduth, S. Wang, and D. L. Urban. 2013. Streams in the urban heat island: spatial and temporal variability in temperature. Freshwater Science 32:309-326.

Stanley, E. H., M. A. Luebke, M. W. Doyle, and D. W. Marshall. 2002. Short-term changes in channel form and macro invertebrate communities following low-head dam removal. Journal of the North American Benthological Society 21:172-187.

Steinbauer, M. J. 2001. Specific leaf weight as an indicator of juvenile leaf toughness in Tasmanian bluegum (Eucalyptus globulus ssp. globulus): implications for insect defoliation. Australian Forestry 64:32-37.

Sudderth, E. A., and F. A. Bazzaz. 2008. N availability does not modify plant-mediated responses of Trichoplusia ni to elevated CO2. Journal of Plant Ecology 1:187-195.

Suren, A. M., and S. McMurtrie. 2005. Assessing the effectiveness of enhancement activities in urban streams: II. Responses of invertebrate communities. River Research and Applications 21:439-453.

Tanaka, M. O., A. C. A. Ribas, and A. L. T. de Souza. 2006. Macroinvertebrate succession during leaf litter breakdown in a perennial karstic river in Western Brazil. Hydrobiologia 568:493498.

Taylor, B. R., and I. V. Andrushchenko. 2014. Interaction of water temperature and shredders on leaf litter breakdown: a comparison of streams in Canada and Norway. Hydrobiologia 721:77-88. 
718 Tuchman, N. C., R. G. Wetzel, S. T. Rier, K. A. Wahtera, and J. A. Teeri. 2002. Elevated 719 atmospheric $\mathrm{CO}_{2}$ lowers leaf litter nutritional quality for stream ecosystem food webs.

720

721

722

723

724

725

726

727

728

729

730

731

732

733

734

735

736

737

738

739 Global Change Biology 8:163-170.

Vyšná, V., F. Dyer, W. Maher, and R. Norris. 2014. Cotton-strip decomposition rate as a river condition indicator - Diel temperature range and deployment season and length also matter. Ecological Indicators 45:508-521.

Wallace, J. B., W. R. Woodall, and F. F. Sherberger. 1970. Breakdown of leaves by feeding of Peltoperla-Maria nymphs (Plecoptera-Peltoperlidae). Annals of the Entomological Society of America 63:562-+.

Wang, Y., and D. Hong. 2010. The effects of desilting on ecological environment in reservoir area of the Taihu Lake. Page 8 in The second session of the national river management and ecological restoration technology seminar, Hangzhou, China.

Webb, B. W., and F. Nobilis. 1995. Long-term water temperature trends in Austrian rivers. Hydrological Sciences Journal-Journal Des Sciences Hydrologiques 40:83-96.

Wenger, S. J., A. H. Roy, C. R. Jackson, E. S. Bernhardt, T. L. Carter, S. Filoso, C. A. Gibson, W. C. Hession, S. S. Kaushal, E. Martí, J. L. Meyer, M. A. Palmer, M. J. Paul, A. H. Purcell, A. Ramírez, A. D. Rosemond, K. A. Schofield, E. B. Sudduth, and C. J. Walsh. 2009. Twenty-six key research questions in urban stream ecology: an assessment of the state of the science. Journal of the North American Benthological Society 28:1080-1098.

Wenisch, B., D. G. Fernández, E. Szöcs, B. G. Mckie, and R. B. Schäfer. 2017. Does the loss of climate sensitive detritivore species alter leaf decomposition? Aquatic Sciences 79:869879. 
740 Winterbourn, M. J., S. Cadbury, C. Ilg, and A. M. Milner. 2008. Mayfly production in a New

741

742

743

744

745

746

747

748

749

750

751

752

753

754

755

756

757

758

759
Zealand glacial stream and the potential effect of climate change. Hydrobiologia 603:211219.

Woodward, G., D. M. Perkins, and L. E. Brown. 2010. Climate change and freshwater ecosystems: impacts across multiple levels of organization. Philosophical Transactions of the Royal Society B-Biological Sciences 365:2093-2106.

Wu, T.-G., M.-K. Yu, G. Geoff Wang, Y. Dong, and X.-R. Cheng. 2012. Leaf nitrogen and phosphorus stoichiometry across forty-two woody species in Southeast China. Biochemical Systematics and Ecology 44:255-263.

Yan, Y., X. Xiang, L. Chu, Y. Zhan, and C. Fu. 2011. Influences of local habitat and stream spatial position on fish assemblages in a dammed watershed, the Qingyi Stream, China. Ecology of Freshwater Fish 20:199-208.

Yule, C. M., J. Y. Gan, T. Jinggut, and K. V. Lee. 2015. Urbanization affects food webs and leaflitter decomposition in a tropical stream in Malaysia. Freshwater Science 34:702-715.

Yule, C. M., M. Y. Leong, K. C. Liew, L. Ratnarajah, K. Schmidt, H. M. Wong, R. G. Pearson, and L. Boyero. 2009. Shredders in Malaysia: abundance and richness are higher in cool upland tropical streams. Journal of the North American Benthological Society 28:404-415.

Zhao, W., H. Wang, H. Wang, and X. Liu. 2009. Conversion methods of freshwater snail tissue dry mass and ash-free dry mass. Chinese Journal of Applied Ecology 20:1452-1458. 
Figure 1

Averages of water temperature in ambient and warming treatments.

(A) water temperature. (B) diel temperature oscillation. Values are mean $\pm \mathrm{SE}$. The symbol * above the bar indicates a significant difference between the treatments.

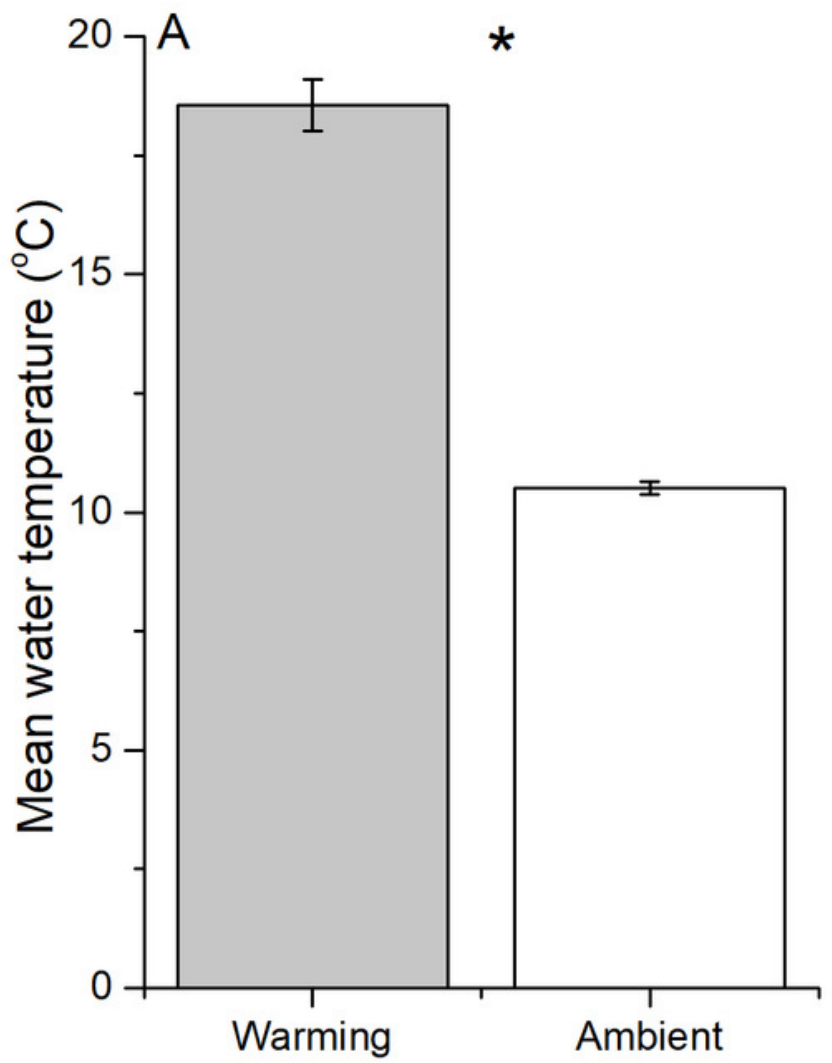

Treatment

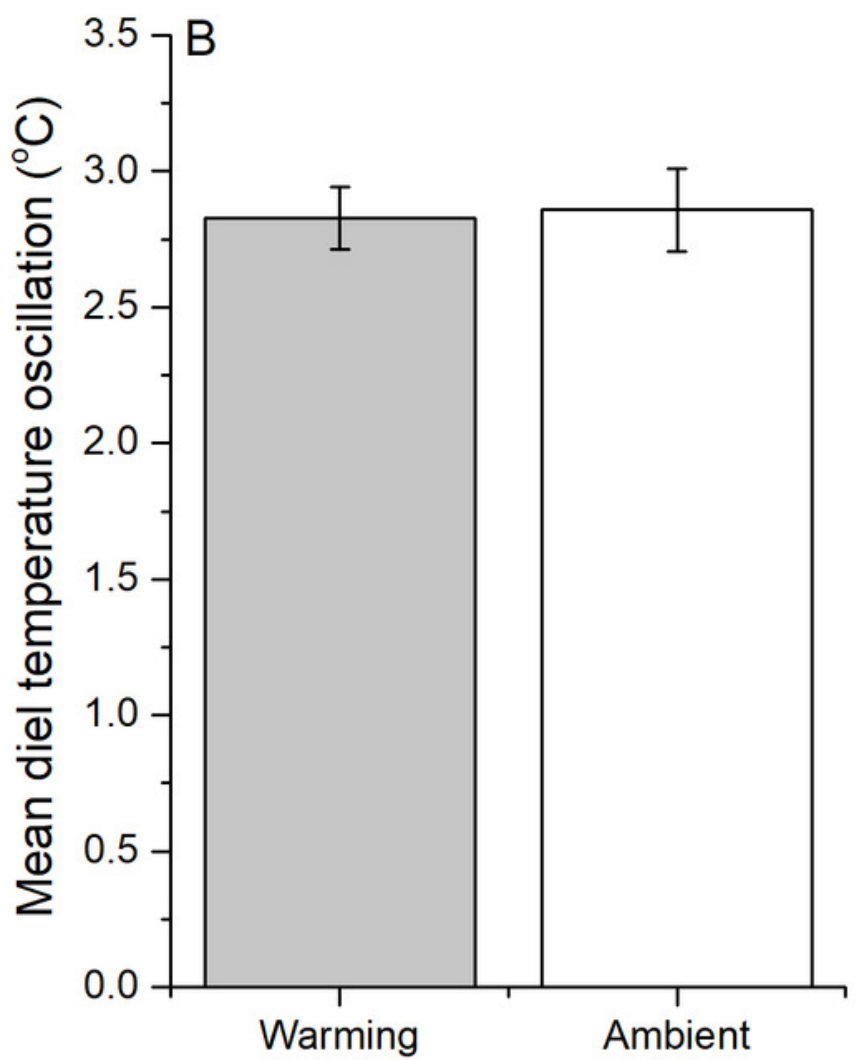

Treatment 
Figure 2

Averages of water quality across the experimental treatments (water temperature: ambient and warming, snails: presence/absence, litter quality: intact and insect damaged).

Values are mean \pm SE (data of three sampling dates are combined). Text in rectangles indicates significant directional main effects and two-way interaction effects (water temperature: T, Snails: S, litter quality: Q), with effect classifications (for abbreviations see Table 1) in parentheses.
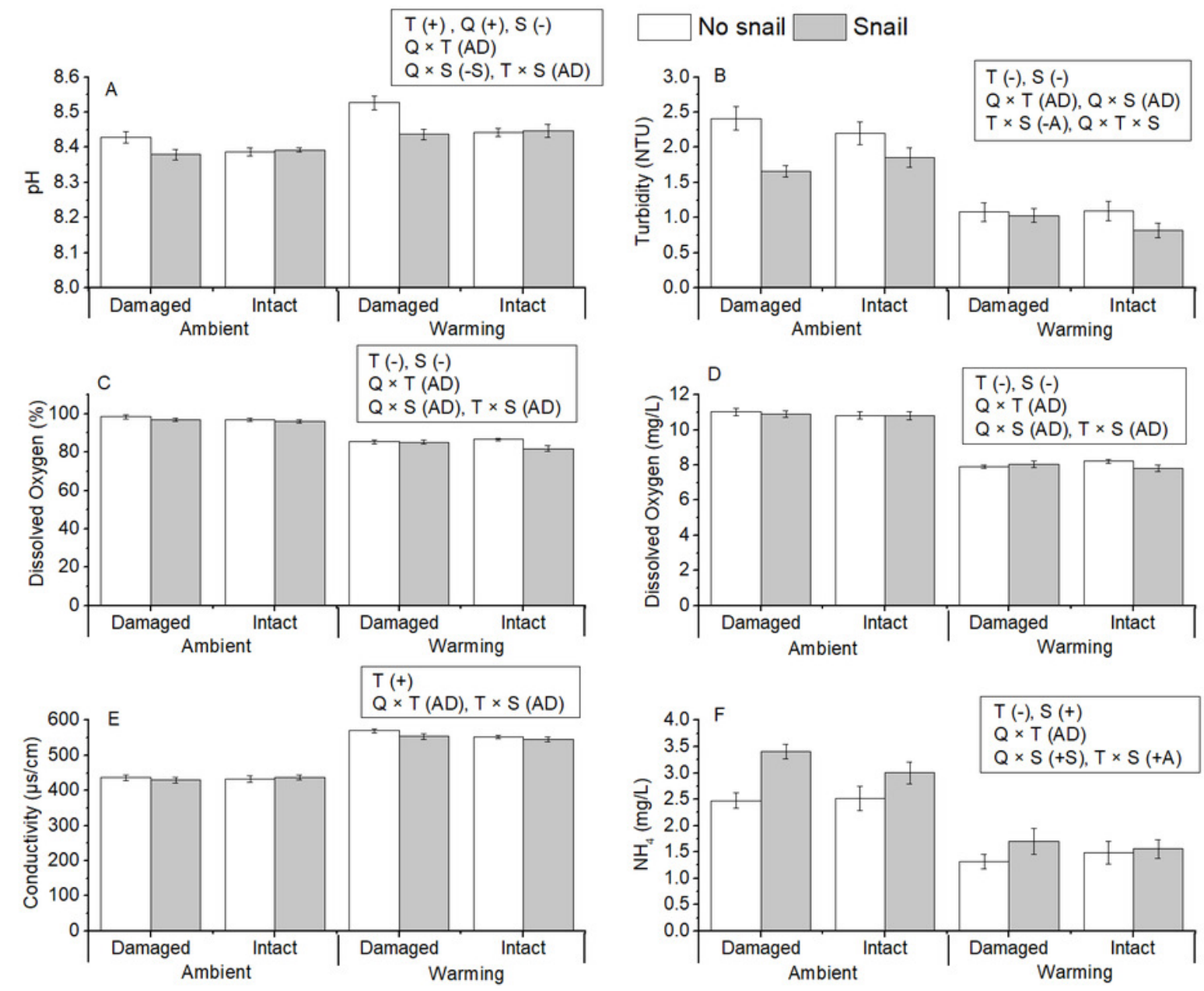
Figure 3

Averages of litter decomposition rates.

litter decomposition rate $\left(k, \mathrm{~d}^{-1}\right)$ for intact $(<5 \%)$ and damaged leaves $(>40 \%$ leaf area were grazed by terrestrial insects) incubated in the absence (blank bar) and presence of snails (light grey bar), at ambient and warming mesocosms for 25 days. Text in rectangles indicate significant directional main effects and two-way interaction effects (water temperature: T, Snails: S, litter quality: Q), with effect classifications (for abbreviations see Table 1 ) in parentheses. Values are mean $\pm \mathrm{SE}$.

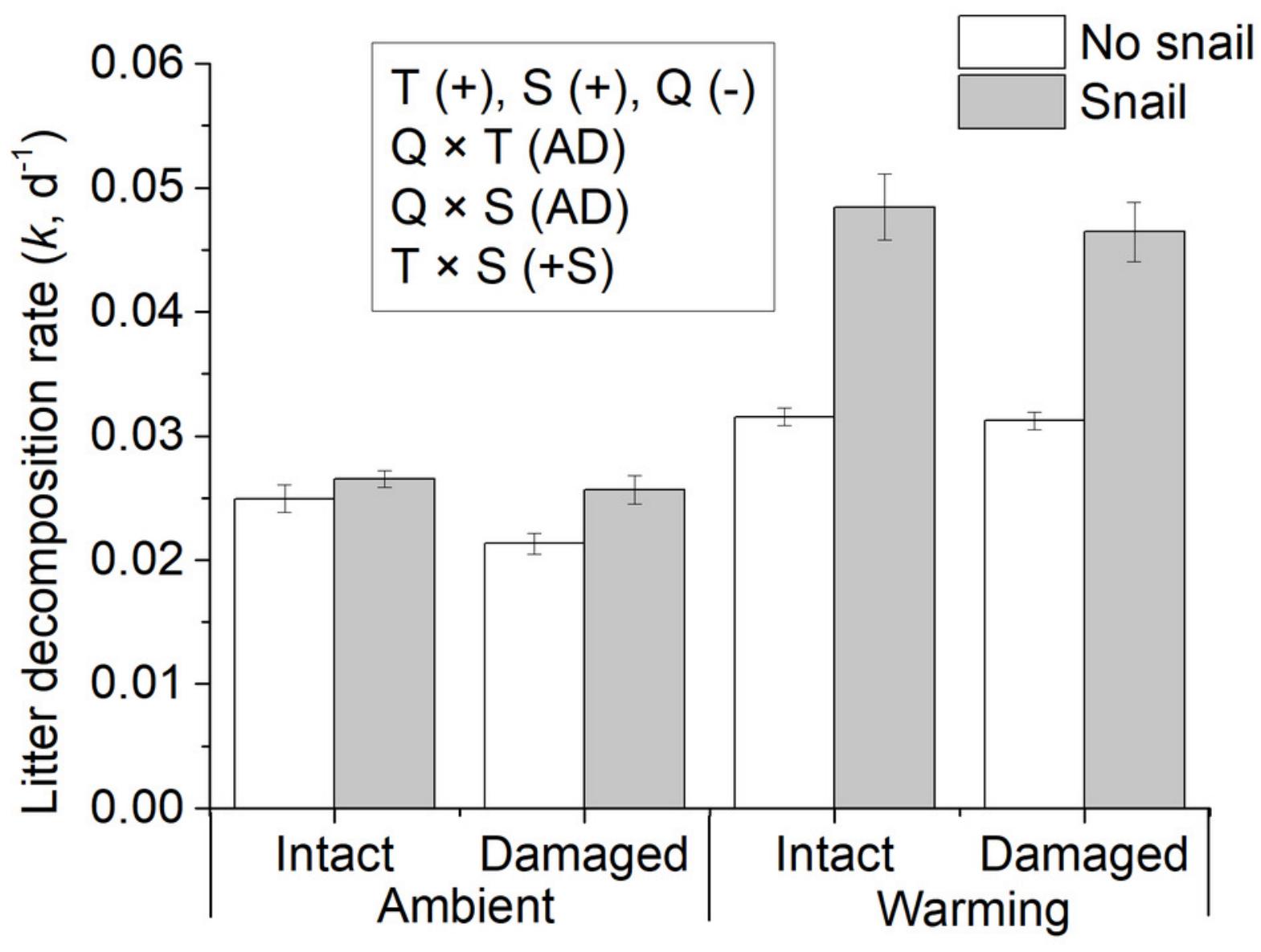


Figure 4

Averages of litter decomposition rates of $(A)$ total, $(B)$ microbes, and $(C)$ snails for intact and insect-damaged leaf litter at ambient and warming $\left(\sim 8{ }^{\circ} \mathrm{C}\right.$ higher) conditions.

Different lowercase letters above each bar indicate significant differences after one-way ANOVA and post hoc Tukey (parameters with same letter are not significantly different between treatments). Text in rectangles indicate significant directional main effects and twoway interaction effects (water temperature: T, litter quality: Q), with effect classifications (for abbreviations see Table 1 ) in parentheses. Values are mean $\pm \mathrm{SE}$.

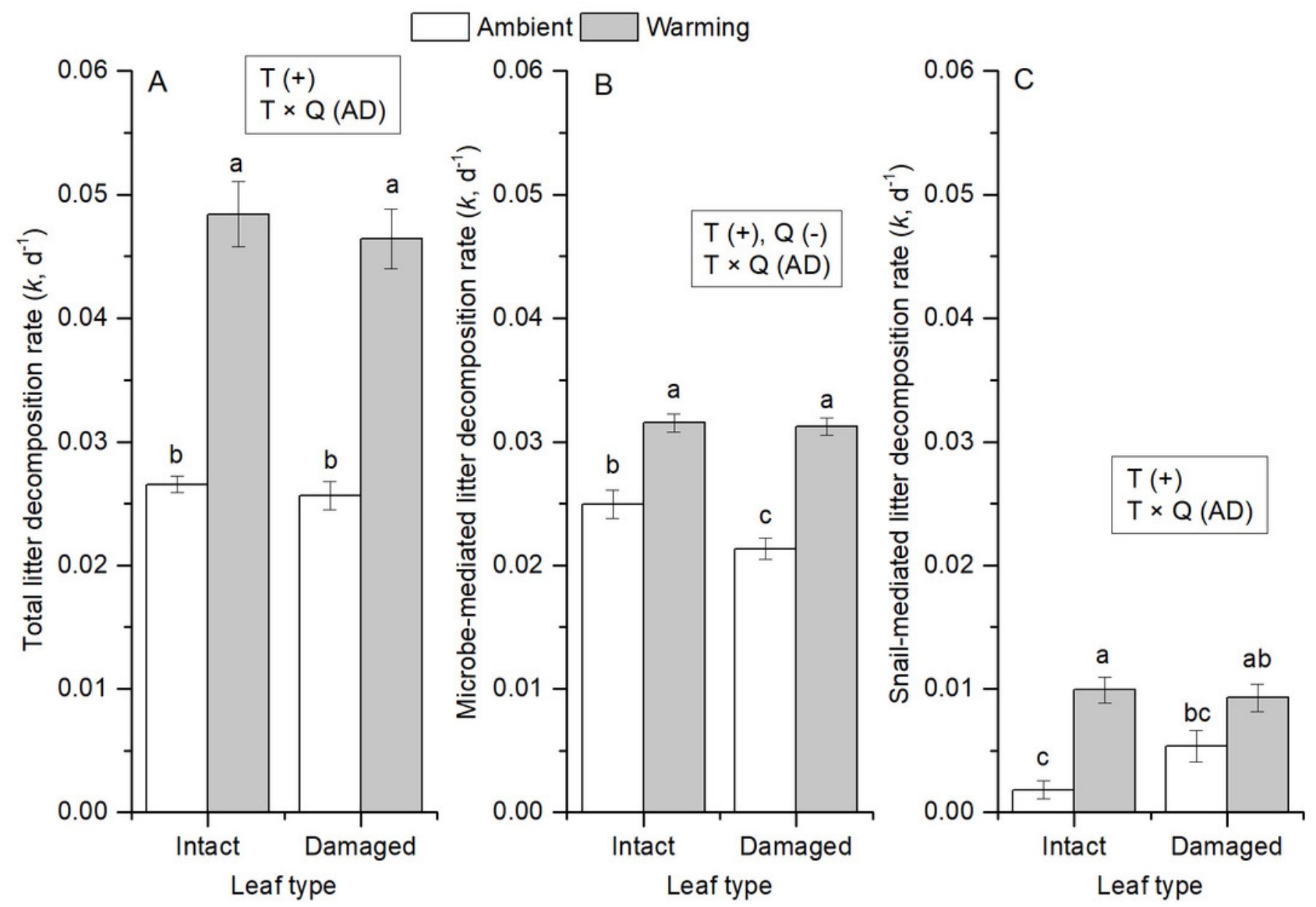


Figure 5

Averages of snail (A) growth rate, (B) initial blotted dry biomass in treatments of intact and insect-damaged litter at ambient and warming condition.

Values are mean \pm SE. Different lowercase letters above each bar indicate significant differences after one-way ANOVA and post hoc Tukey (parameters with same letter are not significantly different between treatments).
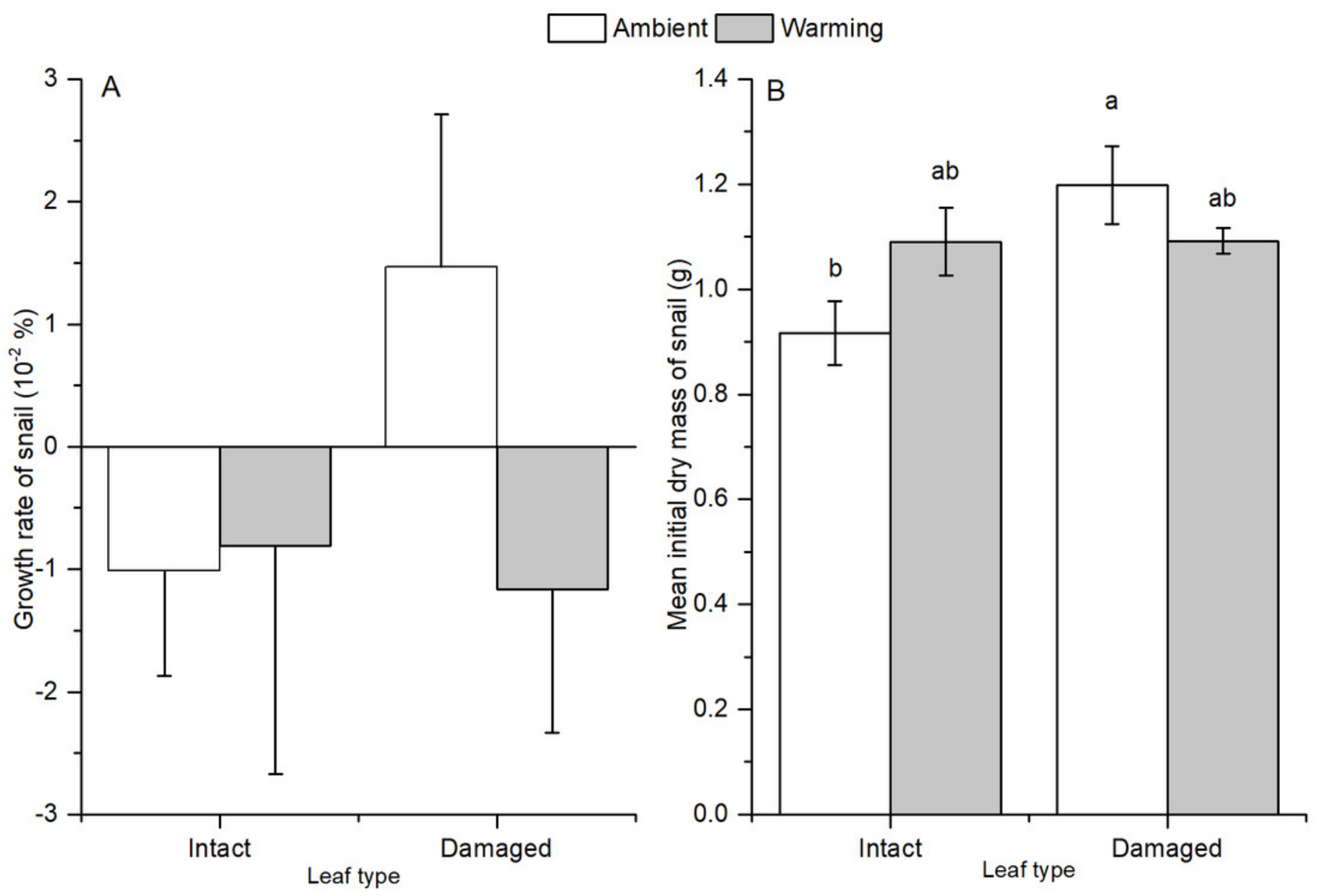


\section{Table $\mathbf{1}$ (on next page)}

Summary results of three-way ANOVA with repeated measures for the effects of water temperature $(\mathrm{T})$, snail $(\mathrm{S})$, and litter quality $(\mathrm{Q})$ on water quality in experimental mesocosms.

Significant main effects are classified directionally as positive $(+)$ or negative (-). Combined (C) two-way interaction effects are classified directionally ( + or -) as antagonistic (A), synergistic (S), additive (AD; no interaction) or no significant effect of either stressor (O) according to the conceptual model proposed by Piggott et. al. (2015). P-values $<0.05$ are in bold print. Effect sizes (partial eta squared values; range 0-1) are shown in parentheses for all cases where $\mathrm{P}<0.1$. 
1 Table 1 Summary results of three-way ANOVA with repeated measures for the effects of water 2 temperature (T), snail (S), and litter quality (Q) on water quality in experimental mesocosms.

3 Significant main effects are classified directionally as positive $(+)$ or negative (-). Combined (C) 4 two-way interaction effects are classified directionally ( + or -$)$ as antagonistic (A), synergistic 5 (S), additive (AD; no interaction) or no significant effect of either stressor $(\mathrm{O})$ according to the 6 conceptual model proposed by Piggott et. al. (2015). $P$-values $<0.05$ are in bold print. Effect 7 sizes (partial eta squared values; range 0-1) are shown in parentheses for all cases where $P<0.1$.

\begin{tabular}{|c|c|c|c|c|c|c|c|c|c|c|c|c|c|}
\hline $\begin{array}{l}\text { Dependent } \\
\text { variables }\end{array}$ & $\begin{array}{l}\text { Litter } \\
\text { quality }\end{array}$ & Q & $\begin{array}{l}\text { Temper } \\
\text { ature }\end{array}$ & $\mathrm{T}$ & Snails & $\mathrm{S}$ & $\mathrm{Q} \times \mathrm{T}$ & $\mathrm{C}$ & $\mathrm{Q} \times \mathrm{S}$ & $\mathrm{C}$ & $\mathrm{T} \times \mathrm{S}$ & $\mathrm{C}$ & $\mathrm{Q} \times \mathrm{T} \times \mathrm{S}$ \\
\hline $\mathrm{pH}$ & $\begin{array}{l}\mathbf{0 . 0 0 3} \\
(0.248)\end{array}$ & + & $\begin{array}{l}<\mathbf{0 . 0 0 1} \\
(0.686)\end{array}$ & + & $\begin{array}{l}<\mathbf{0 . 0 0 1} \\
(0.344)\end{array}$ & - & 0.149 & $\mathrm{AD}$ & $\begin{array}{l}<\mathbf{0 . 0 0 1} \\
(0.402)\end{array}$ & $-\mathrm{S}$ & 0.2 & $\mathrm{AD}$ & 0.215 \\
\hline Turbidity (NTU) & 0.313 & & $\begin{array}{l}<\mathbf{0 . 0 0 1} \\
(0.93)\end{array}$ & - & $\begin{array}{l}<\mathbf{0 . 0 0 1} \\
(0.615)\end{array}$ & - & 0.394 & $\mathrm{AD}$ & 0.383 & $\mathrm{AD}$ & $\begin{array}{l}\mathbf{0 . 0 0 1} \\
(0.318)\end{array}$ & $-A$ & $\begin{array}{l}\mathbf{0 . 0 0 3} \\
(0.244)\end{array}$ \\
\hline $\begin{array}{l}\text { Conductivity } \\
(\mu \mathrm{s} / \mathrm{cm})\end{array}$ & 0.422 & & $\begin{array}{l}<\mathbf{0 . 0 0 1} \\
(0.904)\end{array}$ & + & 0.356 & & 0.315 & $\mathrm{AD}$ & 0.475 & $\mathrm{O}$ & 0.476 & $\mathrm{AD}$ & 0.996 \\
\hline DO (\%) & 0.163 & & $\begin{array}{l}<\mathbf{0 . 0 0 1} \\
(0.891)\end{array}$ & - & $\begin{array}{l}\mathbf{0 . 0 2 7} \\
(0.143)\end{array}$ & - & 0.928 & $\mathrm{AD}$ & 0.227 & $\mathrm{AD}$ & 0.403 & $\mathrm{AD}$ & $\begin{array}{l}0.092 \\
(0.086)\end{array}$ \\
\hline $\mathrm{DO}(\mathrm{mg} / \mathrm{L})$ & 0.684 & & $\begin{array}{l}<\mathbf{0 . 0 0 1} \\
(0.941)\end{array}$ & - & 0.445 & & 0.454 & $\mathrm{AD}$ & 0.383 & $\mathrm{O}$ & 0.827 & $\mathrm{AD}$ & 0.228 \\
\hline Ammonia (mg/L) & 0.325 & & $\begin{array}{l}<\mathbf{0 . 0 0 1} \\
(0.887)\end{array}$ & - & $\begin{array}{l}<\mathbf{0 . 0 0 1} \\
(0.492)\end{array}$ & + & 0.252 & $\mathrm{AD}$ & $\begin{array}{l}\mathbf{0 . 0 3} \\
(0.14)\end{array}$ & $+\mathrm{S}$ & $\begin{array}{l}\mathbf{0 . 0 0 7} \\
(0.206)\end{array}$ & $+\mathrm{A}$ & 0.7 \\
\hline
\end{tabular}




\section{Table 2 (on next page)}

Summary (P-values and effect sizes) of three-way ANOVA comparing litter decomposition rates among experimental treatments (Litter quality: Q, water temperature: $\mathrm{T}$, snails: $\mathrm{S}$ ).

Main effects (M) are classified as positive (+) or negative (-). Combined two-way interaction effects (C) are classified directionally (+ or -) as antagonistic (A), synergistic (S), additive (AD; no interaction) or no significant effect of either stressor (O) according to the conceptual model proposed by Piggott et. al. (2015). P $<0.05$ are in bold print. Effect sizes (partial eta squared values; range $0-1$ ) are shown in parentheses for all cases where $P<0.1$. 
1 Table 2 Summary ( $P$-values and effect sizes) of three-way ANOVA comparing litter

2 decomposition rates (exponential model) among experimental treatments (Litter quality: Q,

3 water temperature: T, snails: S). Main effects (M) are classified as positive (+) or negative (-).

4 Combined two-way interaction effects (C) are classified directionally (+ or -) as antagonistic (A),

5 synergistic (S), additive (AD; no interaction) or no significant effect of either stressor (O)

6 according to the conceptual model proposed by Piggott et. al. (2015). $P<0.05$ are in bold print.

7 Effect sizes (partial eta squared values; range 0-1) are shown in parentheses for all cases where

$8 \quad P<0.1$.

\begin{tabular}{|c|c|c|c|c|}
\hline \multirow[t]{2}{*}{ Treatments } & \multirow[t]{2}{*}{$\mathrm{df}$} & \multicolumn{3}{|c|}{ Decomposition rate $\left(k, \mathrm{~d}^{-1}\right)$} \\
\hline & & $F$ & $P$ & $\mathrm{M} / \mathrm{C}$ \\
\hline Q & 1 & 4.687 & $\mathbf{0 . 0 3 8}(0.128)$ & - \\
\hline $\mathrm{T}$ & 1 & 259.930 & $<\mathbf{0 . 0 0 1}(0.890)$ & + \\
\hline $\mathrm{S}$ & 1 & 90.210 & $<\mathbf{0 . 0 0 1}(0.738)$ & + \\
\hline $\mathrm{Q} \times \mathrm{T}$ & 1 & 1.595 & 0.216 & $\mathrm{AD}$ \\
\hline $\mathrm{Q} \times \mathrm{S}$ & 1 & 0.588 & 0.449 & $\mathrm{AD}$ \\
\hline $\mathrm{T} \times \mathrm{S}$ & 1 & 25.503 & $<\mathbf{0 . 0 0 1}(0.444)$ & $+\mathrm{S}$ \\
\hline $\mathrm{Q} \times \mathrm{T} \times \mathrm{S}$ & 1 & 1.808 & 0.188 & \\
\hline Error & 32 & & & \\
\hline
\end{tabular}

9 Note: Data of litter decomposition rates were log transformed to improve normality before

10 conducting the analysis. 


\section{Table 3 (on next page)}

Summary of two-way ANCOVA comparing the effects of snail initial blotted dry mass (S), water temperature $(\mathrm{T})$ and litter quality $(\mathrm{Q})$ on total, microbe, and snail mediated litter decomposition rates.

Main effects (M) are classified as positive (+) or negative (-). Combined two-way interaction effects (C) are classified directionally ( + or - ) as antagonistic (A), synergistic (S), additive (AD; no interaction) or no significant effect of either stressor (O) according to the conceptual model proposed by Piggott et. al. (2015). P $<0.05$ are in bold print. Effect sizes (partial eta squared values; range $0-1$ ) are shown in parentheses for all cases where $P<0.1$. 
1 Table 3 Summary ( $P$-values and effect sizes) of two-way ANCOVA comparing the individual 2 and combined effects of snail initial blotted dry mass $(\mathrm{S})$, water temperature $(\mathrm{T})$ and litter quality 3 (Q) on total $\left(k_{\text {total }}\right)$, microbe $\left(k_{\text {microbe }}\right)$, and snail $\left(k_{\text {snail }}\right)$ mediated litter decomposition rates. Main 4 effects (M) are classified as positive $(+)$ or negative (-). Combined two-way interaction effects 5 (C) are classified directionally (+ or -) as antagonistic (A), synergistic (S), additive (AD; no 6 interaction) or no significant effect of either stressor $(\mathrm{O})$ according to the conceptual model 7 proposed by Piggott et. al. (2015). $P<0.05$ are in bold print. Effect sizes (partial eta squared 8 values; range $0-1$ ) are shown in parentheses for all cases where $P<0.1$.

\begin{tabular}{|c|c|c|c|c|c|c|c|c|c|c|}
\hline \multirow{2}{*}{$\begin{array}{l}\text { Treatment } \\
\mathrm{s}\end{array}$} & $\mathrm{df}$ & \multicolumn{3}{|l|}{$k_{\text {total }}$} & \multicolumn{3}{|l|}{$k_{\text {microbe }}$} & \multicolumn{3}{|l|}{$k_{\text {snail }}$} \\
\hline & & $F$ & $P$ & $\mathrm{M} / \mathrm{C}$ & $F$ & $P$ & $\mathrm{M} / \mathrm{C}$ & $F$ & $P$ & $\mathrm{M} / \mathrm{C}$ \\
\hline $\mathrm{T}$ & 1 & 113.558 & $\begin{array}{l}<\mathbf{0 . 0 0 1} \\
(0.883)\end{array}$ & + & 85.408 & $\begin{array}{l}<\mathbf{0 . 0 0 1} \\
(0.851)\end{array}$ & + & 30.008 & $\begin{array}{l}<0.001 \\
(0.667)\end{array}$ & + \\
\hline Q & 1 & 0.714 & 0.411 & & 5.417 & $\begin{array}{l}\mathbf{0 . 0 3 4} \\
(0.265)\end{array}$ & - & 1.170 & 0.296 & \\
\hline S & 1 & 0.179 & 0.678 & & 0.650 & 0.433 & & 0.016 & 0.902 & \\
\hline $\mathrm{T} \times \mathrm{Q}$ & 1 & 0.001 & 0.982 & $\mathrm{AD}$ & 4.194 & $\begin{array}{l}0.058 \\
(0.219)\end{array}$ & $\mathrm{AD}$ & 2.499 & 0.135 & $\mathrm{AD}$ \\
\hline Error & 16 & & & & & & & & & \\
\hline
\end{tabular}




\section{Table 4 (on next page)}

Summary (P-values and effect sizes) of two-way ANOVA comparing snail growth rates for the individual and combined effects of litter quality $(Q)$ and water temperature $(T)$.

Main effects (M) are classified as positive (+) or negative (-). Combined two-way interaction effects (C) are classified directionally (+ or -) as antagonistic (A), synergistic (S), additive (AD; no interaction) or no significant effect of either stressor (O) according to the conceptual model proposed by Piggott et. al. (2015). P $<0.05$ are in bold print. Effect sizes (partial eta squared values; range $0-1$ ) are shown in parentheses for all cases where $P<0.1$. 
1 Table 4 Summary ( $P$-values and effect sizes) of two-way ANOVA comparing snail growth rates

2 for the individual and combined effects of litter quality (Q) and water temperature (T). Main

3 effects (M) are classified as positive (+) or negative (-). Combined two-way interaction effects

4 (C) are classified directionally ( + or - ) as antagonistic (A), synergistic (S), additive (AD; no

5 interaction) or no significant effect of either stressor $(\mathrm{O})$ according to the conceptual model

6 proposed by Piggott et. al. (2015). $P<0.05$ are in bold print. Effect sizes (partial eta squared

7 values; range $0-1$ ) are shown in parentheses for all cases where $P<0.1$.

\begin{tabular}{lllll} 
Treatments & df & \multicolumn{3}{c}{ Snail growth rate } \\
\cline { 2 - 5 } & & \multicolumn{4}{c}{$F$} & M/C \\
\hline $\mathrm{T}$ & 1 & 0.881 & 0.363 & \\
$\mathrm{Q}$ & 1 & 0.187 & 0.671 & \\
Initial & 1 & 0.201 & 0.66 & \\
biomass & & & & \\
$\mathrm{T} \times \mathrm{Q}$ & 1 & 0.434 & 0.52 & $\mathrm{O}$ \\
Error & 15 & & & \\
\end{tabular}

8

9 